Article

\title{
Land-Surface Characteristics and Climate in West Africa: Models' Biases and Impacts of Historical Anthropogenically-Induced Deforestation
}

\author{
Souleymane Sy ${ }^{1,2,3, *(\mathbb{C})}$, Nathalie de Noblet-Ducoudré ${ }^{4}$, Benjamin Quesada 5 (D), Ibrahima Sy ${ }^{2}$, \\ Amadou Moctar Dieye ${ }^{2}$, Amadou Thierno Gaye ${ }^{1}$ and Benjamin Sultan ${ }^{3}$ \\ 1 Laboratoire de Physique de l'Atmosphère et de l'Océan Siméon-Fongang (LPAO-SF), \\ Ecole Supérieure Polytechnique, Cheikh Anta Diop University, B.P. 5005 Dakar-Fann, Senegal; \\ atgaye@ucad.edu.sn \\ 2 Centre de Suivi Ecologique, Fann-Résidence, B.P. 15532 Dakar-Fann, Senegal; ibrahima.sy@cse.sn (I.S.); \\ dieye@cse.sn (A.M.D.) \\ 3 Laboratoire d'Océanographie et du Climat: Expérimentations et Approches Numériques (LOCEAN), \\ Sorbonne Universités (UPMC, Univ Paris 06)-CNRS-IRD-MNHN, 75005 Paris, France; \\ benjamin.sultan@locean-ipsl.upmc.fr \\ 4 Laboratoire des Sciences du Climat et de l'Environnement (LSCE), Unité Mixte CEA-CNRS-UVSQ Bât. 712, \\ Point Courrier 132, 91191 Gif-sur-Yvette CEDEX, France; nathalie.de-noblet@lsce.ipsl.fr \\ 5 Institute of Meteorology and Climate Research-Karlsruhe Institute of Technology (IMK-IFU, KIT), \\ 82467 Garmisch-Partenkirchen, Germany; benjamin.quesada@kit.edu \\ * Correspondence: souleymane.sy@ucad.edu.sn; Tel.: +221-77-442-98-50
}

Received: 31 August 2017; Accepted: 12 October 2017 ; Published: 23 October 2017

\begin{abstract}
Land Use Land-Cover Change (LULCC), such as deforestation, affects the climate system and land-atmosphere interactions. Using simulations carried out within the LUCID (Land Use and Climate, IDentification of robust Impacts) project framework, we first quantify the role of historical land-cover change induced by human activities on surface climate in West Africa. Focusing on two contrasted African regions, we find that climate responses of land-use changes are small but they are still statistically significant. In Western Sahel, a statistically significant near-surface atmospheric cooling and a decrease in water recycling are simulated in summer in response to LULCC. Over the Guinean zone, models simulate a significant decrease in precipitation and water recycling in autumn in response to LULCC. This signal is comparable in magnitude with the effect induced by the increase in greenhouse gases. Simulated climate changes due to historical LULCC could however be underestimated because: (i) the prescribed LULCC can be underestimated in those regions; (ii) the climate models underestimate the coupling strength between West African surface climate and leaf area index (LAI) and (iii) the lack of interactive LAI in some models. Finally, our study reveals indirect atmospheric processes triggered by LULCC. Over the Western Sahel, models reveal that a significant decrease in solar reflection tends to cool down the surface and thus counteracts the atmospheric feedback. Conversely, over the Guinea zone, models reveal that the indirect atmospheric processes and turbulent heat fluxes dominate the climatic responses over the direct effects of LULCC.
\end{abstract}

Keywords: climate change; deforestation; land use-land cover change; land-atmosphere interaction; land surface models; LUCID; West Africa 


\section{Introduction}

Humans have radically modified the land cover distribution to the gains of urbanization and agriculture activities. Nearly $35 \%$ of the available land surface has been directly converted into anthropic systems [1]. Nowadays, there is no doubt that Land Use induced Land Cover Change (LULCC) through deforestation, reforestation, or conversion of natural vegetation has been geographically extensive [1-8]. In the upcoming decades, nearly a million hectares of forest fraction could continue to disappear, particularly in the tropical regions [9]. At global scale, LULCC has a direct effect on biophysical properties of land surfaces. LULCC in particular is related to the reduction of forest fractions and of natural savannah, to the gains of settings crops and pastures, and this trend was observed on a global scale during the last few decades [10-13]. If this current trend continues, the cultivated surface could increase by $20 \%$ during the next 50 years [14].

LULCC affects the land surface properties in different ways strongly determined by the type of change. The magnitude of impact of deforestation for agriculture depends on the spatial scale of the change. It also depends on the type of natural vegetation which is removed, since a coniferous forest interacts with the atmosphere differently than a deciduous forest; and both systems differ significantly from a native grassland or savannah system [15].

LULCC affects climate and land-atmosphere interactions mainly by altering the physical characteristics of the land surface such as albedo, soil moisture and roughness. The climate modelling community, benefiting from recent progress in land-surface models (LSMs), has demonstrated the impact of land cover perturbation on surface temperature, rainfall, and turbulent energy fluxes over many different regions of the world [12,13,16-20].

However, the way in which LULCC affects climate and land-atmosphere interactions is a complex question because of the large number of complex linked processes at the surface-atmosphere interface, the competing impacts, as well as uncertainties related to the representation of these processes in state of the art land surface models. In this respect, the intercomparison project "Land Use and Climate, IDentification of robust Impacts" (LUCID; [12,13,21,22]) has represented a major step forward towards a better understanding of the biophysical impacts, using a common simulation framework between different LSMs. LUCID experiments were designed to investigate the LULCC effects on climate using prescribed sea surface temperatures (SSTs) and sea ice model experiments, with a focus on resulting land-atmosphere interactions. The goal of the LUCID project is to identify impacts that are statistically robust, primarily in terms of being detectable, common among the different employed models, and focusing on signals that exceed the models' internal variability. LULCC is prescribed based on historical data starting from the beginning of the industrial revolution to present day conditions $[1,3]$.

Preliminary results from the LUCID project were discussed by Pitman et al. [12], who mainly focused on the Northern Hemisphere summer season. They investigated the impact of land cover changes on the atmosphere from pre-industrial period to present-day, using several Atmospheric General Circulation Models (AGCMs). They showed that model simulations in temperate regions indicate substantial changes in latent and sensible heat fluxes, albedo, and near-surface air temperature. Nevertheless, the magnitude of LULCC and its effect on surface-atmosphere interactions varied considerably among models and regions. Reasons for discrepancies are likely related to differences in the land surface parameterizations, particularly for crops and pastures among the different LSMs (see $[12,13,21,22])$.

The land surface has been shown to be an important factor in modulating the West African monsoon (WAM). For example, based on observations, land surface characteristics and processes have a significant impact on the inter-annual rainfall variability in the Sahel region [23]. The importance of surface-atmosphere interactions was one of the main tenets of the recent international African Monsoon Multidisciplinary Analysis (AMMA) project [24] and this was investigated in several studies (see [25] for an overview). 
Among the regions where land surface-atmosphere interactions play a major role, West Africa has been highlighted to be an important hot spot $[18,26,27]$. The West African Monsoon (WAM) flow is driven by land-sea thermal contrast. The atmosphere-land surface interactions are further modulated by the magnitude of the north-south gradient of heat and moisture in the lower atmosphere [28]. The links between land surface processes and the WAM have been discussed in numerical studies based on global climate models (GCMs) and regional-scale atmospheric climate models (RCMs) ([29]). Charney [30] was one of the first researcher to use a coupled land surface-atmosphere model. Charney proposed a positive vegetation/precipitation feedback mechanism relating a decrease in vegetation cover to increased drought conditions across the Sahel region. Since then, numerous modeling studies have examined the influence of the land surface on the WAM in terms of surface albedo (e.g., [31,32]), vegetation distribution (e.g., [33-35]), and soil moisture (e.g., [36-40]).

However, results based on these studies need to be taken with great caution as there are substantial discrepancies in the strength of the African land-atmosphere coupling as simulated by different GCMs [18]. Such discrepancies have been highlighted by the West African Monsoon Modeling and Evaluation (WAMME) project which inter-compared such models to address issues regarding the role of ocean-land-aerosol-atmosphere interactions on WAM dynamics [41]. The recent phase II of WAMME project provides a basic and better understanding of LULCC forcing on the regional climate of West Africa [42,43]. The employed strategy consists in applying observational data-based anomaly forcing, i.e., "idealized" anomaly in GCM and RCM simulations. The prescribed LULCC is based on land cover data derived from [4]. This data was utilized to design a "maximum feasible degradation scenario". During WAMME II, Boone et al. [43] imposed consistent biogeophysical responses of surface parameters to LULCC using a simple experimental setup. The prescribed LULCC corresponded to degraded vegetation conditions, which mainly caused an increase in the Bowen ratio and a decrease in the surface net radiation. These effects resulted in a significant reduction in surface evaporation over a large part of the Sahel.

There is increasing scientific evidence from numerical studies that anthropogenic LULCC can potentially induce significant variations at the local to regional scale [44]. Despite those know evidences, the IPCC's Fifth Assessment lacked a comprehensive evaluation of the relative impact of biogeophysical feedbacks of LULCC on regional climate $[45,46]$. Thus, many questions remain open regarding the response of local, regional, and global climate to changes in biophysical surface properties in response to land-cover change.

This study further investigates biophysical impacts of historical LULCC on surface climate in West Africa using the LUCID multi-model experiments. The main objectives are: (1) to describe and quantify the impacts of historical LULCC on surface climate in West African regions; (2) to compare those impacts to the ones caused by an increased amount of atmospheric greenhouse gases; and (3) to check whether more realistic land-cover description may improve climate model simulations over West African regions.

The model experiments from the LUCID project and the observation data sets are presented in Section 2, together with changes in land-cover since pre-industrial times. Section 3 presents a validation of rainfall and temperature as simulated by the climate models over two contrasted regions of West Africa: the Sahel and Guinea. Section 4 evaluates leaf area index as simulated by the LUCID models, and discusses how land-cover changes affect surface climate through changes in land surface characteristics and fluxes at the biosphere-atmosphere interface. Finally, Section 5 discusses the main findings, with an emphasis on changes caused by an increase in atmospheric greenhouse gases concentration since the pre-industrial time period. 


\section{Data and Methods}

\subsection{LUCID Simulations}

In this study, we used the seven GCMs involved in the LUCID project [12,13,21,22]. The LSMs embedded in each GCM (hereafter GCM/LSMs), and their references are listed in Table 1. In the following, we will use the name of the GCM provided in Table 1 to ease reading of the text and figures' legends. Four types of simulations were conducted by GCMs groups to evaluate the impact of LULCC between the pre-industrial period and present day. Each experiment includes an ensemble (five members) of 30-years simulations, computed with prescribed sea surface temperatures SSTs and sea-ice extent (SIC), atmospheric $\mathrm{CO}_{2}$ concentrations $\left(\left[\mathrm{CO}_{2}\right]\right)$ and land-cover maps Table 2. All models used the same SST/SIC dataset as boundary conditions (HadISST dataset of [47] and a combined crop/pasture data set derived from [1,3] respectively. The land cover maps were created based on the combined historical cropland and pasture distribution from SAGE [1] and the History Database the Global Environment (HYDE) [3] datasets (see Figure 1). SAGE has developed a "data fusion" technique to integrate remotely sensed data on the world's land cover with administrative-unit-level inventory data on land use (see $[1,48,49])$. The HYDE database was originally carried out for testing and validation of the IMAGE 2 model [50]. The Land cover map for agricultural land is based on a combination of a georeference dataset and national land use statistic (please see [3]).

Pre-industrial (PI) and present-day (PD) experiments are driven by prescribed data for the corresponding period. Inter-annual variability is solely prescribed in the SSTs and SIC forcing; the land use and greenhouse gases forcings are kept constant for a particular year (Table 2). The $P D_{V}$ experiment was carried out using the present-day SST, SIC and $\left[\mathrm{CO}_{2}\right]$ (hereafter CO2SST) and pre-industrial vegetation conditions (set to 1870). The $P I_{V}$ experiment is forced by pre-industrial $\mathrm{CO}_{2}$ and SST with the current vegetation conditions (1992). All simulations have been run in an ensemble mode ( $n=5$ ensembles per model, by perturbing the initial atmospheric conditions) to include more robustness in the results reported herein. 
Table 1. List of Climate Models and associated Land Surface Models used in the LUCID set of experiments.

\begin{tabular}{|c|c|c|c|c|c|c|c|}
\hline $\begin{array}{l}\text { Climate } \\
\text { or Atmopheric } \\
\text { Models (reference) }\end{array}$ & $\begin{array}{l}\text { ARPEGE } \\
\text { (Salas-Mélia et al. [51]) }\end{array}$ & $\begin{array}{l}\text { CCAM } \\
\text { (McGregor and Dix [52]) }\end{array}$ & $\begin{array}{l}\text { CCSM } \\
\text { (Collins et al. [53]) }\end{array}$ & $\begin{array}{l}\text { ECEARTH (www. } \\
\text { ecmwf. int/ research/ } \\
\text { ifsdocs / CY31r1/) }\end{array}$ & ECHAM5 (Roeckner [54]) & IPSL (Marti et al. [55]) & $\begin{array}{l}\text { SPEEDY } \\
\text { (Strengers et al. [56]) }\end{array}$ \\
\hline $\begin{array}{l}\text { Land Surface } \\
\text { Models (reference) }\end{array}$ & ISBA ([57]) & CABLE (Wang et al. [58]) & $\begin{array}{l}\text { CLM } \\
\text { (Oleson et al. [59]) }\end{array}$ & $\begin{array}{l}\text { TESSEL } \\
\text { (van den Hurk et al. [60]) }\end{array}$ & JSBACH (Raddatz et al. [61]) & $\begin{array}{l}\text { ORCHIDEE } \\
\text { (Krinner et al. [62]) }\end{array}$ & LPJmL (Bondeau et al. [63]) \\
\hline $\begin{array}{l}\text { Background } \\
\text { land-cover }\end{array}$ & ECOCLIMAP [64] & Present day & Potential [65] & AVHRR [66] & Potential [5] & AVHRR [66] & Potential (computed) \\
\hline Total PFT number & 12 & 12 & 15 & 16 & 12 & 12 & 11 \\
\hline Crops representation & $\begin{array}{l}3 \text { specifics PFTs (C3, C4 } \\
\text { and irrigated) }\end{array}$ & 1 PFT (C3) & 1 PFT (C3) & 1 PFT & $1 \mathrm{PFT}$ & 2 PFTs (C3 and C4) & 2 PFTs (C3 and C4) \\
\hline $\begin{array}{l}\text { Pastures } \\
\text { representation }\end{array}$ & As natural grass & As crop & $\begin{array}{l}\text { As } \mathrm{C} 3 / \mathrm{C} 4 \text { natural } \\
\text { grass }\end{array}$ & As crop & As $\mathrm{C} 3 / \mathrm{C} 4$ natural grass & $\begin{array}{l}\text { As } \mathrm{C} 3 / \mathrm{C} 4 \text { natural } \\
\text { grass }\end{array}$ & $\begin{array}{l}\text { Managed C3/C4 grassland } \\
\text { with intensive cutting cycles }\end{array}$ \\
\hline $\begin{array}{l}\text { Crops } \\
\text { integration strategy }\end{array}$ & $\begin{array}{l}\text { Proportional reduction of } \\
\text { natural vegetation }\end{array}$ & $\begin{array}{l}\text { Grid-cell filled up with } \\
\text { crop if the combined crop } \\
\text { and pasture fraction }>50 \%\end{array}$ & $\begin{array}{l}\text { Proportional reduction } \\
\text { of natural vegetation }\end{array}$ & $\begin{array}{l}\text { Reduction of low } \\
\text { vegetation first and of } \\
\text { forest secondarily }\end{array}$ & $\begin{array}{l}\text { Reduction of low vegetation } \\
\text { first and of forest secondarily }\end{array}$ & $\begin{array}{l}\text { Proportional reduction } \\
\text { of natural vegetation }\end{array}$ & $\begin{array}{l}\text { Proportional reduction of } \\
\text { natural vegetation }\end{array}$ \\
\hline $\begin{array}{l}\text { Phenology } \\
\text { traitement }\end{array}$ & $\begin{array}{l}\text { Prescribed } \\
\text { LAI seasonal cycle }\end{array}$ & $\begin{array}{l}\text { Prescribed } \\
\text { LAI seasonal cycle }\end{array}$ & $\begin{array}{l}\text { Prescribed } \\
\text { LAI seasonal cycle }\end{array}$ & $\begin{array}{l}\text { Fixed } \\
\text { LAI (no seasonallecycle) }\end{array}$ & Computed LAI & Computed LAI & Computed LAI \\
\hline
\end{tabular}


Table 2. List of LUCID simulations analyzed in this paper.

\begin{tabular}{cccc}
\hline Experiment Name $^{\mathbf{a}}$ & SST/SIC Period & CO $_{\mathbf{2}}$ (ppm) & Land Cover Year \\
\hline PD & $1970-1999$ & 375 & 1992 \\
PDV $_{\text {VI }}$ & $1970-1999$ & 375 & 1870 \\
PI $_{\mathbf{V}}$ & $1870-1899$ & 280 & 1870 \\
\hline
\end{tabular}

a Each experiment includes five members of ensemble simulations. For further details about the prescribed forcing (land-cover data, sea-surface temperature/sea-ice concentrations data (SST/SIC) and atmospheric $\mathrm{CO}_{2}$ concentrations) and the experiment setup and model descriptions, please see [13].

\subsection{Observation-Based Data Sets}

To evaluate the performance of the seven climate models used in LUCID simulation, several climate observation datasets were used. Rainfall and surface air temperature simulated by the LUCID climate models were compared to observational data from the Climatic Research Unit (CRU) which is available at spatial resolution of $0.5 \times 0.5^{\circ}$ from 1901 to 2016 (http:/ / www.cru.uea.ac.uk, [67]). The Leaf Area Index (LAI) satellite derived dataset from the Geoland2 project (http:/ / www.copernicus.eu/projects / geoland2, [68]) is used to assess the reliability of LSMs to simulate realistic LAI. The LAI dataset is available at $0.5 \times 0.5^{\circ}$ spatial resolution with a 10 days temporal resolution for the period 1982-2000. All climate model outputs and observational data set were linearly interpolated to a common rectilinear grid at $2.0^{\circ} \times 2.0^{\circ}$ resolution .

\subsection{Changes in Land Cover Fraction between 1870 and 1992}

The changes in the extent of crops and pastures cover between the PD (1992) and PI (1870) periods are not homogeneous over West Africa (Figure 1). In the Sahel zone, LULCC increased over northwestern Senegal, Mauritania, parts of Mali, central Burkina Faso, the north of Nigeria, southern Niger, Chad and Sudan. In the Guinea zone, the extension of cropland and pasture is located in the South of Ivory Coast, Ghana, Guinea Conakry and Liberia. Although all LSMs embedded in the LUCID climate models used the same crop and pasture extents for 1870 and 1992, modelers have implemented them using different procedures to incorporate the agricultural data into their own standard vegetation maps. In other words, the various LSMs used different way to characterize the subgrid land cover heterogeneity. For example, all of them have defined a number of plant functional types (PFTs) to parameterize specific vegetation types, but share a different number of them within the grid-cell (see Table 1 for more details). This can induced significant differences in the deforestation rates that each LSM deduced between the preindustrial times and present-day and, therefore, in the simulated climate responses to LULCC.

The land cover maps prescribed in the seven LSMs is consistent with our knowledge of agricultural geography even if there are some limitations about the uncertainties to identifying what has been the actual anthropogenic LULCC. This dataset is similar to the data which is now being used for producing historical simulations [8] (Figure 1, Table 3) of the Intergovernmental Panel on Climate Change (IPCC) Coupled Model Intercomparison Project phase 5 (CMIP5). However, many factors can explain the discrepancies between reconstructed vegetation cover maps. They can due to errors in satellite data acquisition, data processing, information extraction methodologies, inadequate ancillary training data, as well as the relatively course resolution in current climate models. Current satellite-derived vegetation maps have difficulties with respect to adequately present realistic LULCC information. This is relevant in West Africa, where the agricultural area is generally poorly classified and distinction between pasture and crop fraction can be difficult, since the animals will very often graze crop fields after the harvest period ass discussed in Boone et al. [43]. However, there are many uncertainties in identifying what has been the actual anthropogenic LULCC (see [22]). One source of uncertainty results from the reconstruction of the historical record and spatial distribution of cropland and pastureland. Another source of uncertainty may arise from current land cover characterization. Moreover, we 
know less about the specificities of land conversion to croplands (i.e., deforestation or conversion from previously grass-covered area) and cover characterization as discussed in Feddema et al. [69] and the previous LUCID papers (please see de Noblet-Ducoudré et al. [13]). However, there are some initiatives that started to address this issue (see $[4,8]$ ).
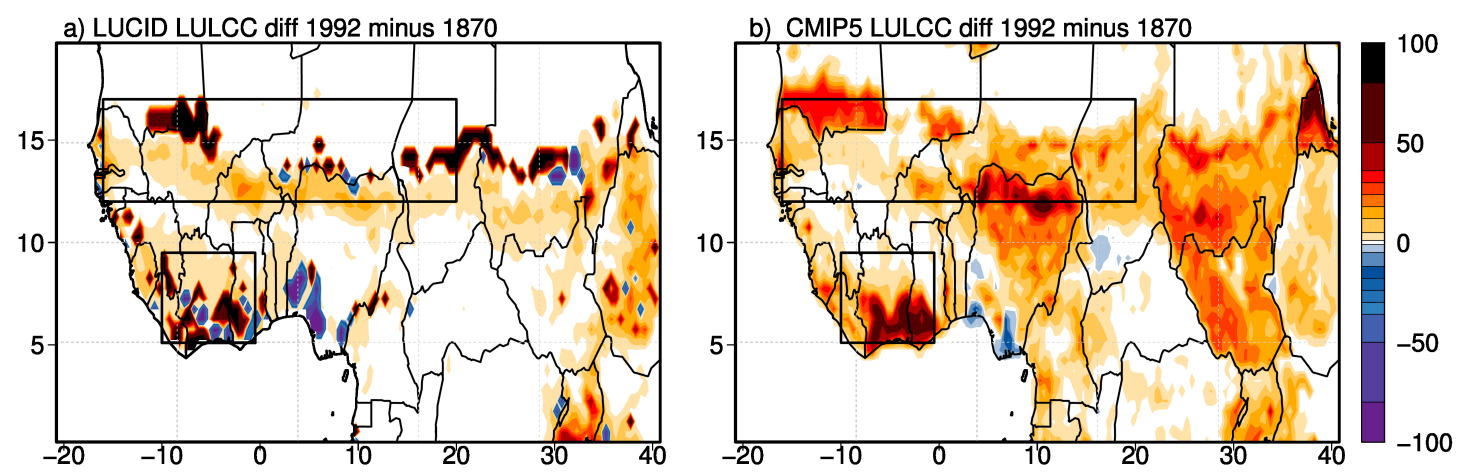

Figure 1. Changes in total crop and pasture extent between 1992 and 1870 expressed in \% of each pixel. The red and orange colors represent an expansion of those areas while the blue colors show abandoned areas. The rectangular boxes depicted the Sahel and Guinea zones where changes in total crop and pasture are larger than $8 \%$.

Table 3. Changes in the extent covered by all crops and pastures (fractions expressed in \%) between 1992 and 1870 in the Sahel and the Guinea zones.

\begin{tabular}{ccc}
\hline \multicolumn{4}{c}{$\Delta$ Crops + Pastures } & $(\mathbf{1 9 9 2}-\mathbf{8 7 0 )}$ \\
\hline Area & LUCID & CMIP5 \\
\hline Sahel & 8.64 & 9.70 \\
Guinea & 11.20 & 14.89 \\
\hline
\end{tabular}

The biophysical effects related to LULCC are calculated from the difference between PD and PDv (PD-PDv) simulations averaged over the 1970-1999 period (30 years). Historical "LULCC intensity" (or $\Delta$ Forest Fraction) is defined for each model as the simulated changes in total crop and pasture extent between 1992 and 1870 (Figure 2). Historical LULCC is implemented in different ways among the different LUCID models (see Figure 3). Interpretation of land use classes, crop, and pasture areas differs between LSMs since each model integrated the crops and pasture distributions provided for both periods into its own land cover map or from prognostic simulations of vegetation distribution (see [13]). In addition, five out of seven models have chosen to proportionally reduce/extend all natural vegetation for grid cells which are not occupied by crops and/or pasture, while the remaining two have first reduced the grassland area and then forests. Other differences between resulting maps come from (1) the number of vegetation types accounted for per grid cell and (2) various configurations of the background land cover map utilized among different modeling groups. A detailed description of land use change maps implementation, and interpretation of land use classes can be found in de Noblet-Ducoudré et al. [13].

In both regions, we note that changes in the total (Crops + Pastures) extent between 1992 and 1870 are quite small in the LSMs $(\leq 8 \%)$. In the Guinea zone, imposed expansion of crops and pastures fraction is well reproduced by most LSMs with a reduction of the forests fraction with the exception of the CCAM model. In most LSMs, the biogeography is represented through Plant Functional Types (PFTs). CCAM only considers grid cells that are occupied by the dominant vegetation type, so if one type exceeds the $50 \%$ threshold, then it is set to occupy the whole grid cell. Although areas covered by crops and grassland increase in most models from pre-industrial times to the present, the intensity of fractional area covered by each types of vegetation and their relative changes is varying remarkably 
among models. Depending on the model, the grid cell includes one (CCAM), two (ECEARTH), or multiple PFTs (CCSM, ECHAM5, IPSL, SPEEDY). For the ARPEGE model, a set of parameters, averaged from those of different PFTs co-existing within each grid-cell, describes vegetation related grid properties. For the Sahel zone, crops and grass fractions have expanded predominantly at the expense of forests in the IPSL and ECEARTH models, while in ARPEGE and SPEEDY models the increase of desert areas is larger than the reduction in forests. In CCAM, CCSM, ECHAM5 models the reduction in herbaceous areas is as large or even larger than the reduction in forests. In LSMs that mix crops and grasses (1 PFT instead of 2), an expansion of previous grassland area will not change the fluxes exchanged with the atmosphere (e.g., in ARPEGE).
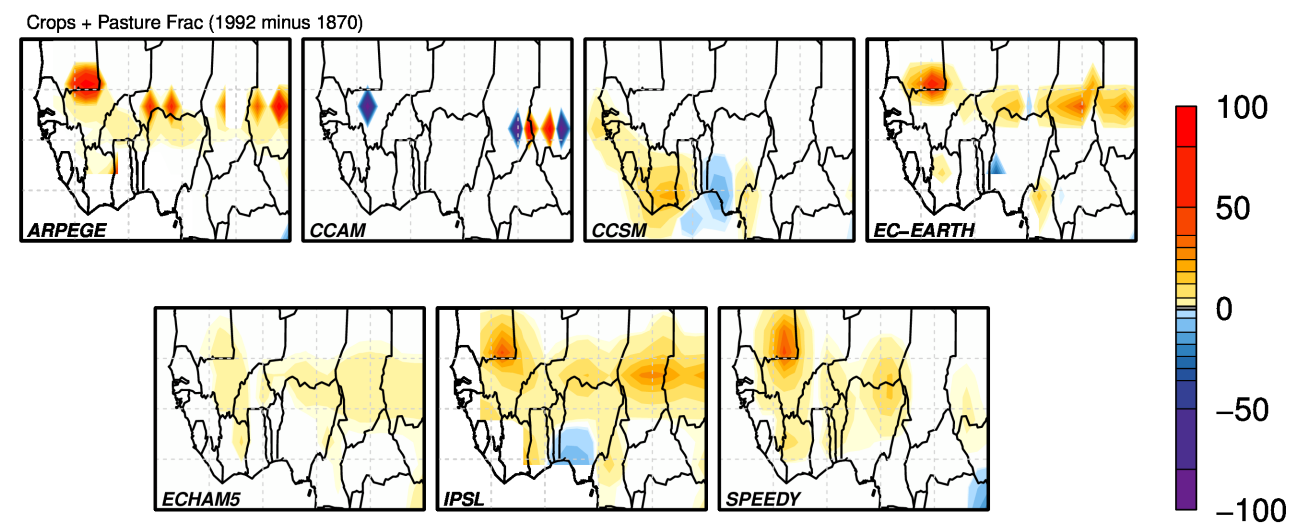

Figure 2. Changes in the total ( $\triangle$ Crops + Pastures) extent between 1992 and 1870 expressed in \% of each pixel, for each LUCID model. The red and orange colors represent an expansion of those areas while the blue colors show abandoned areas.
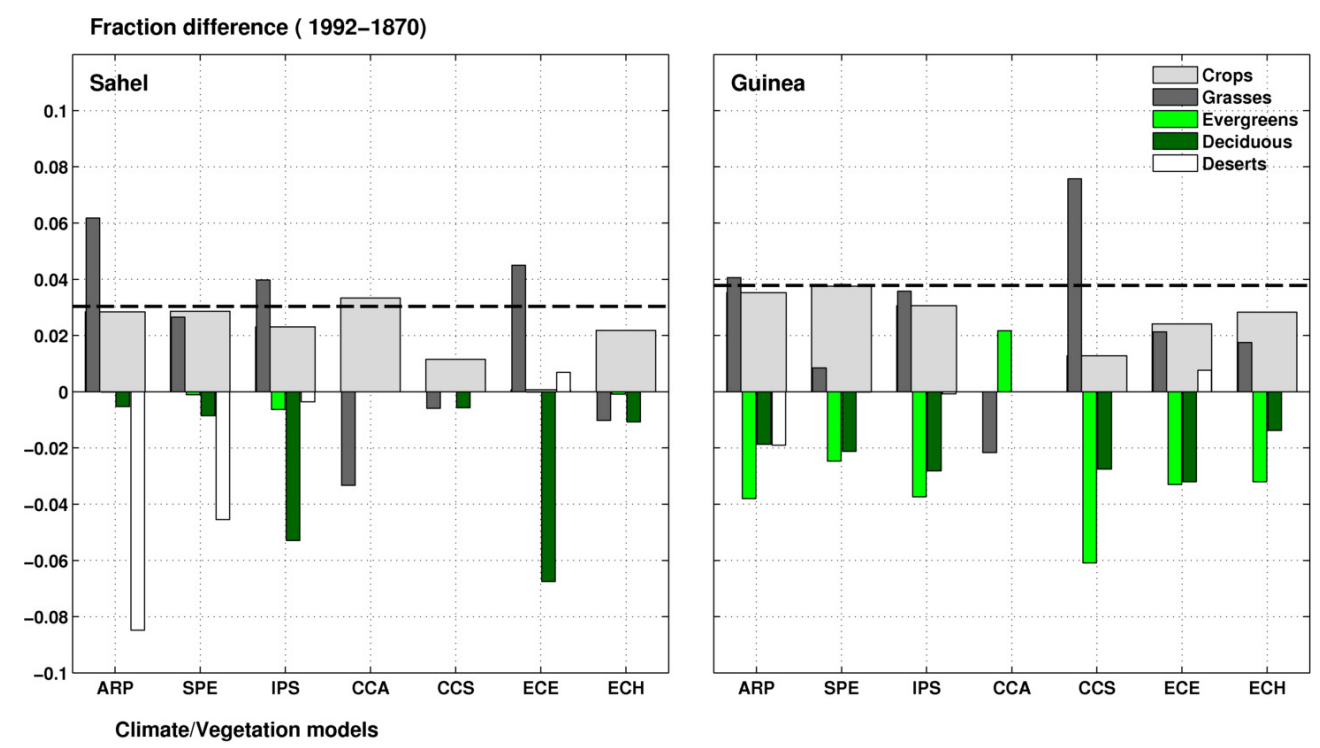

Figure 3. Fractional changes ((PD-PI)/PI) in the areas occupied by crops (light grey), pasture (dark grey), evergreen trees (light green), deciduous trees (dark green) and deserts (white) in the Sahel (left panel) and the Guinean regions (right panel). The dotted line shows the observed changes in the extent covered by crops fractions between 1992 and 1870, based on Ramankutty and Foley [1]. ARP, CCA, CCS, ECE, ECH, IPS and SPE are used to identify the GCM/LSMs models, respectively ARPEGE/ISBA, CCAM/CABLE, CCSM/CLM, ECEARTH/TESSEL, ECHAM5/JSBACH, IPSL/ORCHIDEE and SPEEDY/LPJmL. 


\subsection{Separating the Respective Impacts of Land-Cover and Greenhouse Gas Changes}

To separate the respective contribution of LULCC from the increase in atmospheric $\mathrm{CO}_{2}$ greenhouse gases $\left(\mathrm{SST} / \mathrm{CO}_{2}\right)$ since pre-industrial times, we focused in this study on two regions: the Sahel zone $\left(15^{\circ} \mathrm{W}-20^{\circ} \mathrm{E}\right.$ and $\left.12^{\circ} \mathrm{N}-18^{\circ} \mathrm{N}\right)$ and the Guinea zone $\left(10^{\circ} \mathrm{W}-0^{\circ} \mathrm{E}\right.$ and $\left.5^{\circ} \mathrm{N}-10^{\circ} \mathrm{N}\right)$ where the changes in the sum of crop and pasture extent between 1992 and 1870 exceeds $8 \%$ (Figure 1). For a given atmospheric variable $V$ (surface temperature or precipitation for example), its response to LULCC between 1992 and 1870 is calculated as:

$$
\Delta V_{L U L C C}=V_{P D}-V_{P D_{V}}
$$

In the following, $V$ is a seasonal average value for each experiment. The change in $V$ in response to the combined changes in sea surface temperature (SSTs), the extension of the sea ice concentration (SIC) and the increase in atmospheric $\mathrm{CO}_{2}$ greenhouse gases $\left.\left(\mathrm{SST} / \mathrm{CO}_{2}\right)\right)$ between the present day and pre-industrial periods is calculated as follows:

$$
\Delta V_{C O 2 S S T}=V_{P D}-V_{P I_{V}}
$$

We particularly looked at changes in the Surface Energy Budget (SEB):

$$
\begin{aligned}
Q_{S N}+Q_{L D} & =Q_{T}+Q_{L U}+Q_{G} \\
Q_{S N} & =(1-\alpha) Q_{S D}
\end{aligned}
$$

where $Q_{S N}$ and $Q_{S D}$ are respectively the net and downward shortwave radiation, $Q_{L D}$ and $Q_{L U}$ are respectively the downward and upward long-wave radiation, $Q_{T}$ is the sum of the latent $\left(Q_{L E}\right)$ and sensible $\left(Q_{H}\right)$ heat fluxes, $Q_{G}$ in a residual term (all values are in $\mathrm{Wm}^{-2}$ ), and $\alpha$ is the surface albedo. In order to have a closed SEB relation, $Q_{G}$ is derived explicitly from the other terms in Equation (3), and accounts for the energy fluxes which are not considered here (the flux of heat being transmitted to deeper soil layers).

\section{Evaluation of Surface Climate, and of How It Is Affected by Land Cover Change}

\subsection{Are Precipitation and Surface Air Temperature Well Simulated by the Models?}

The LUCID models are compared to observed rainfall and surface air temperature data for the Sahelian and Guinean zones. Results for the rainy season solely are depicted in Figure 3 and Table 3 provides a summary for rainy season and annual means as well as information regarding inter-annual variability (estimated from standard deviation). Observed mean daily rainfall in summer (from June to September) is respectively $2.7 \mathrm{~mm} /$ day and $6.4 \mathrm{~mm} /$ day in the Sahel and Guinea zones (Table 4). Three out of seven LUCID models underestimate observed rainfall in the Sahel zone (ECHAM, IPSL, SPEEDY), three tend to overestimate it (CCAM, CCSM, ECEARTH), while one simulates about the right amount of rainfall (ARPEGE). In the Guinea zone, ARPEGE, SPEEDY and ECEARTH overestimate rainfall, IPSL simulates the right order of magnitude and the other three models underestimate it (CCAM, CCSM, ECHAM). The models' ensemble mean provides the best estimate of rainfall in the Sahel zone which corroborates previous studies (e.g., [41,70]). 
Table 4. Simulated annual (only for June-September in brackets) average (MEAN) and standard deviation (STD) of rainfall (mm/day) and surface air temperature $\left({ }^{\circ} \mathrm{C}\right)$ for each climate models and for the the multi-model ensemble mean (ENSMEAN). This is carried out for both the Sahel and Guinea zone. PD and PDv simulation are compared to observations (OBS) data-set over the 1970-1999 period.

\begin{tabular}{|c|c|c|c|c|c|c|c|c|}
\hline \multirow{3}{*}{$\begin{array}{l}\text { CGM } \\
\text { MEAN }\end{array}$} & \multicolumn{4}{|c|}{ Precipitation } & \multicolumn{4}{|c|}{ Near Surface Temperature } \\
\hline & \multicolumn{2}{|c|}{ Sahel } & \multicolumn{2}{|c|}{ Guinea } & \multicolumn{2}{|c|}{ Sahel } & \multicolumn{2}{|c|}{ Guinea } \\
\hline & PD & $\mathrm{PD}_{\mathrm{V}}$ & PD & $\mathrm{PD}_{\mathrm{V}}$ & PD & $\mathrm{PD}_{\mathrm{V}}$ & PD & $\mathrm{PD}_{\mathrm{V}}$ \\
\hline ARPEGE & $1.31(2.92)$ & $1.26(2.82)$ & $4.12(5.02)$ & $4.15(5.11)$ & $27.48(31.04)$ & $27.62(31.23)$ & $26.19(24.96)$ & $26.25(24.98)$ \\
\hline CCAM & $1.59(3.41)$ & $1.53(3.30)$ & $2.57(3.22)$ & $2.51(3.13)$ & 27.11(28.23) & $27.36(28.79)$ & $33.19(35.98)$ & $33.23(36.00)$ \\
\hline CCSM & $1.48(3.68)$ & $1.60(3.99)$ & $2.18(2.14)$ & $2.16(2.03)$ & $25.52(27.50)$ & $25.56(27.46)$ & 24.93(24.06) & $24.87(24.04)$ \\
\hline ECEARTH & $1.54(3.57)$ & $1.50(3.56)$ & $3.94(5.45)$ & $3.95(5.39)$ & $26.81(28.44)$ & $26.83(28.45)$ & $24.48(23.14)$ & $24.48(23.17)$ \\
\hline ECHAM5 & $0.89(2.27)$ & $0.66(1.74)$ & $2.58(4.06)$ & $2.58(4.09)$ & 26.89(30.99) & 26.84(30.98) & $26.50(25.61)$ & 26.51(24.93) \\
\hline IPSL & $0.44(1.09)$ & $0.44(1.11)$ & $3.46(5.38)$ & $3.45(5.36)$ & $27.00(30.46)$ & $26.98(30.38)$ & $25.89(24.94)$ & $25.86(24.94)$ \\
\hline SPEEDY & $0.93(2.05)$ & $0.98(2.14)$ & $5.21(6.46)$ & $5.38(6.89)$ & $31.29(31.69)$ & $31.38(31.78)$ & $28.09(26.00)$ & 28.17(26.07) \\
\hline ENSMEAN & $1.17(2.73)$ & $1.12(2.65)$ & $3.04(4.06)$ & $3.03(4.03)$ & 26.81(29.59) & $26.88(29.71)$ & $27.19(26.90)$ & $27.20(26.90)$ \\
\hline OBS & \multicolumn{2}{|c|}{$0.99(2.7)$} & \multicolumn{2}{|c|}{$3.63(6.04)$} & \multicolumn{2}{|c|}{$28.46(30.31)$} & \multicolumn{2}{|c|}{$26.42(25.31)$} \\
\hline STD & PD & $\mathbf{P D}_{\mathrm{V}}$ & PD & $\mathbf{P D}_{\mathrm{V}}$ & PD & $\mathbf{P D}_{\mathrm{V}}$ & PD & $\mathrm{PD}_{\mathrm{V}}$ \\
\hline ARPEGE & $0.20(0.46)$ & $0.19(0.42)$ & $0.38(0.66)$ & $0.39(0.61)$ & $0.31(0.54)$ & $0.35(0.57)$ & $0.26(0.33)$ & $0.28(0.35)$ \\
\hline CCAM & $0.42(0.78)$ & $0.42(0.81)$ & $0.38(0.68)$ & $0.45(0.84)$ & $0.59(1.30)$ & $0.89(1.75)$ & $0.70(0.39)$ & $0.71(0.69)$ \\
\hline $\operatorname{CCSM}$ & $0.21(0.59)$ & $0.19(0.57)$ & $0.20(0.42)$ & $0.23(0.42)$ & $0.44(0.49)$ & $0.39(0.52)$ & $0.25(0.34)$ & $0.25(0.35)$ \\
\hline ECEARTH & $0.18(0.45)$ & $0.17(0.42)$ & $0.11(0.27)$ & $0.13(0.32)$ & $0.25(0.47)$ & $0.36(0.41)$ & $0.12(0.09)$ & $0.11(0.11)$ \\
\hline ECHAM5 & $0.07(0.17)$ & $0.12(0.30)$ & $0.19(0.44)$ & $0.16(0.39)$ & $0.34(0.46)$ & $0.35(0.50)$ & $0.38(0.44)$ & $0.32(0.39)$ \\
\hline IPSL & $0.03(0.09)$ & $0.04(0.12)$ & $0.15(0.40)$ & $0.15(0.37)$ & $0.30(0.38)$ & $0.31(0.44)$ & $0.26(0.30)$ & $0.27(0.32)$ \\
\hline SPEEDY & $0.02(0.07)$ & $0.03(0.07)$ & $0.61(0.96)$ & $0.57(0.90)$ & $0.27(0.21)$ & $0.24(0.20)$ & $0.17(0.20)$ & $0.16(0.16)$ \\
\hline ENSMEAN & $0.10(0.22)$ & $0.10(0.26)$ & $0.13(0.26)$ & $0.11(0.25)$ & $0.16(0.35)$ & $0.28(0.49)$ & $0.36(0.51)$ & $0.39(0.52)$ \\
\hline OBS & \multicolumn{2}{|c|}{$0.16(0.45)$} & \multicolumn{2}{|c|}{$0.29(0.77)$} & \multicolumn{2}{|c|}{$0.36(0.46)$} & \multicolumn{2}{|c|}{$0.34(0.33)$} \\
\hline
\end{tabular}

Figure 4 investigates the linear relationship between observed and simulated summer rainfall at the pixel level. Most models have difficulties to representing large precipitation values (larger than $\sim 4 \mathrm{~mm} /$ day in the Sahel zone and than $\sim 6 \mathrm{~mm}$ /day in the Guinea zone) and this is corroborated by the multi-model ensemble mean. CABLE simulates a very low precipitation amount $(\sim 3 \mathrm{~mm} /$ day $)$ over the Sahel zone, while over the Guinea zone rainfall means range between 4 and $5 \mathrm{~mm} /$ day. Two models (CCSM and ECEARTH ) tend to overestimate median rainfall values in the Sahel zone rather than extremes (2-5 $\mathrm{mm} /$ day).

The observed inter-annual variability of rainfall during the rainy season (Table 4 ) is $0.45 \mathrm{~mm} /$ day in the Sahel zone, and $0.77 \mathrm{~mm} /$ day in the Guinea zone. This represents about $15 \%$ of the mean seasonal rainfall in both regions (16\% in the Sahel zone and $12 \%$ in the Guinea zone). In the Sahel zone, absolute rainfall values are overestimated by two climate models (CCAM, CCSM), simulated with the right order of magnitude for two others (ARPEGE, ECEARTH), and underestimated for all others (IPSL, ECHAM, SPEEDY). In the Guinea zone, all climate models but SPEEDY underestimate the observed variability of seasonal rainfall. Table 5 shows the normalized root mean square error (NRMSE) and the correlation between the simulated and the observed rainfall. The climate models show significant differences in the mean bias and the inter-annual variability. In the Sahel zone, only one out of seven climate models (CCSM) and the ensemble mean show a significant correlation with observations. No models simulate a significant correlation in the Guinea zone. Over the Sahel zone, high and significant biases are simulated by four out of seven climate models (CCAM, CCSM, ECHAM5 and SPEEDY) and by two models over the Guinea zone (CCSM and IPSL). The simulated bias and inter-annual variability vary from one model to another resulting in LUCID climate model errors that can be explained to uncertainty in the representation of atmospheric processes (see Section 4.3). As discussed in Flato et al. [71], the representation of cloud processes, including convection and its interaction with boundary layer and larger-scale circulation, remain a major source of uncertainty in the atmospheric climate models. Using multiple regional climate models driven by the ERA-interim reanalysis, Diallo et al. [72] showed that most climate models were able to reproduce the observed 
inter-annual variability of rainfall during the rainy season. They further showed large correlation between simulations and observations due to a good representation of the dynamics of the main West African Monsoon such as the monsoon flux, the African Easterly Jet (AEJ) and Tropical Easterly Jet (TEJ). They conclude that only one climate model failed to reproduce rainfall variability because of its inability to capture the variability of monsoon flow and the relationship between rainfall and the AEJ dynamic. This finding is corroborated by the recent study of Akinsanola et al. [73] that used seven regional climate models carried out in Coordinated Regional climate Downscaling Experiment (CORDEX) project framework to simulate the observed rainfall characteristics over West Africa during the period 1990-2008.

Table 5. Statistical comparisons of seven climate models runs with respect to observation data-set. Normalized Root Mean Square Error (NRMSE) and correlation between the simulated rainfall and temperature (June to September) for each GCM/LSMs, the ensemble mean are calculated with respect to observation over the 1970-1999 period for both regions.

\begin{tabular}{|c|c|c|c|c|c|c|c|c|}
\hline \multirow{3}{*}{$\begin{array}{c}\text { CGM } \\
\text { NRMSE }\end{array}$} & \multicolumn{4}{|c|}{ Precipitation } & \multicolumn{4}{|c|}{ Near Surface Temperature } \\
\hline & \multicolumn{2}{|c|}{ Sahel } & \multicolumn{2}{|c|}{ Guinea } & \multicolumn{2}{|c|}{ Sahel } & \multicolumn{2}{|c|}{ Guinea } \\
\hline & PD & $\mathbf{P D}_{\mathrm{V}}$ & PD & $\mathrm{PD}_{\mathrm{V}}$ & PD & $\mathrm{PD}_{\mathrm{V}}$ & PD & $\mathrm{PD}_{\mathrm{V}}$ \\
\hline ARPEGE & 0.22 & 0.20 & 0.24 & 0.25 & 0.03 & 0.03 & 0.01 & 0.01 \\
\hline CCAM & 0.44 & 0.41 & 0.29 & 0.31 & 0.08 & 0.07 & 0.42 & 0.42 \\
\hline CCSM & 0.44 & 0.53 & 0.33 & 0.33 & 0.09 & 0.09 & 0.05 & 0.05 \\
\hline ECEARTH & 0.22 & 0.39 & 0.24 & 0.24 & 0.05 & 0.05 & 0.07 & 0.07 \\
\hline ECHAM5 & 0.61 & 0.61 & 0.08 & 0.09 & 0.02 & 0.02 & 0.02 & 0.01 \\
\hline IPSL & 0.29 & 0.27 & 0.43 & 0.48 & 0.01 & 0.02 & 0.02 & 0.02 \\
\hline SPEEDY & 0.37 & 0.35 & 0.11 & 0.14 & 0.04 & 0.05 & 0.03 & 0.03 \\
\hline ENSMEAN & 0.14 & 0.18 & 0.08 & 0.08 & 0.01 & 0.02 & 0.05 & 0.05 \\
\hline Correlation & PD & $\mathrm{PD}_{\mathrm{V}}$ & PD & $\mathrm{PD}_{\mathrm{V}}$ & PD & $\mathrm{PD}_{\mathrm{V}}$ & PD & $\mathrm{PD}_{\mathrm{V}}$ \\
\hline ARPEGE & 0.21 & 0.19 & 0.04 & -0.11 & 0.32 & 0.46 & 0.87 & 0.84 \\
\hline CСАМ & 0.09 & -0.13 & 0.07 & 0.06 & -0.09 & -0.20 & 0.18 & 0.22 \\
\hline CCSM & 0.62 & 0.10 & -0.25 & -0.4 & 0.28 & 0.17 & 0.47 & 0.40 \\
\hline ECEARTH & 0.07 & 0.17 & -0.09 & -0.19 & 0.14 & 0.11 & -0.06 & -0.12 \\
\hline ECHAM5 & 0.23 & 0.32 & 0.06 & -0.02 & -0.27 & -0.27 & -0.1 & -0.08 \\
\hline IPSL & 0.20 & 0.01 & 0.23 & 0.16 & 0.38 & 0.35 & 0.38 & 0.46 \\
\hline SPEEDY & 0.02 & -0.14 & -0.01 & 0.16 & 0.11 & 0.05 & 0.23 & 0.19 \\
\hline ENSMEAN & 0.52 & 0.11 & 0.12 & 0.06 & 0.40 & 0.20 & 0.66 & 0.67 \\
\hline
\end{tabular}

Figure 5 and Table 5 show that surface air temperature is better simulated than precipitation in LUCID climate models. Mean observed temperature during the rainy season is $30^{\circ} \mathrm{C}$ in the Sahel zone and $25^{\circ} \mathrm{C}$ in the Guinea zone. Three models (CCAM, CCSM, ECEARTH) underestimate temperature in the Sahel zone, and this is consistent with an overestimation of rainfall during the rainy season. More rainfall suggests increased evapotranspiration and consequently a cooler surface. In Guinea only CCAM strongly overestimates surface air temperature during the rainy season, and this is also consistent with a strong underestimation of rainfall. 

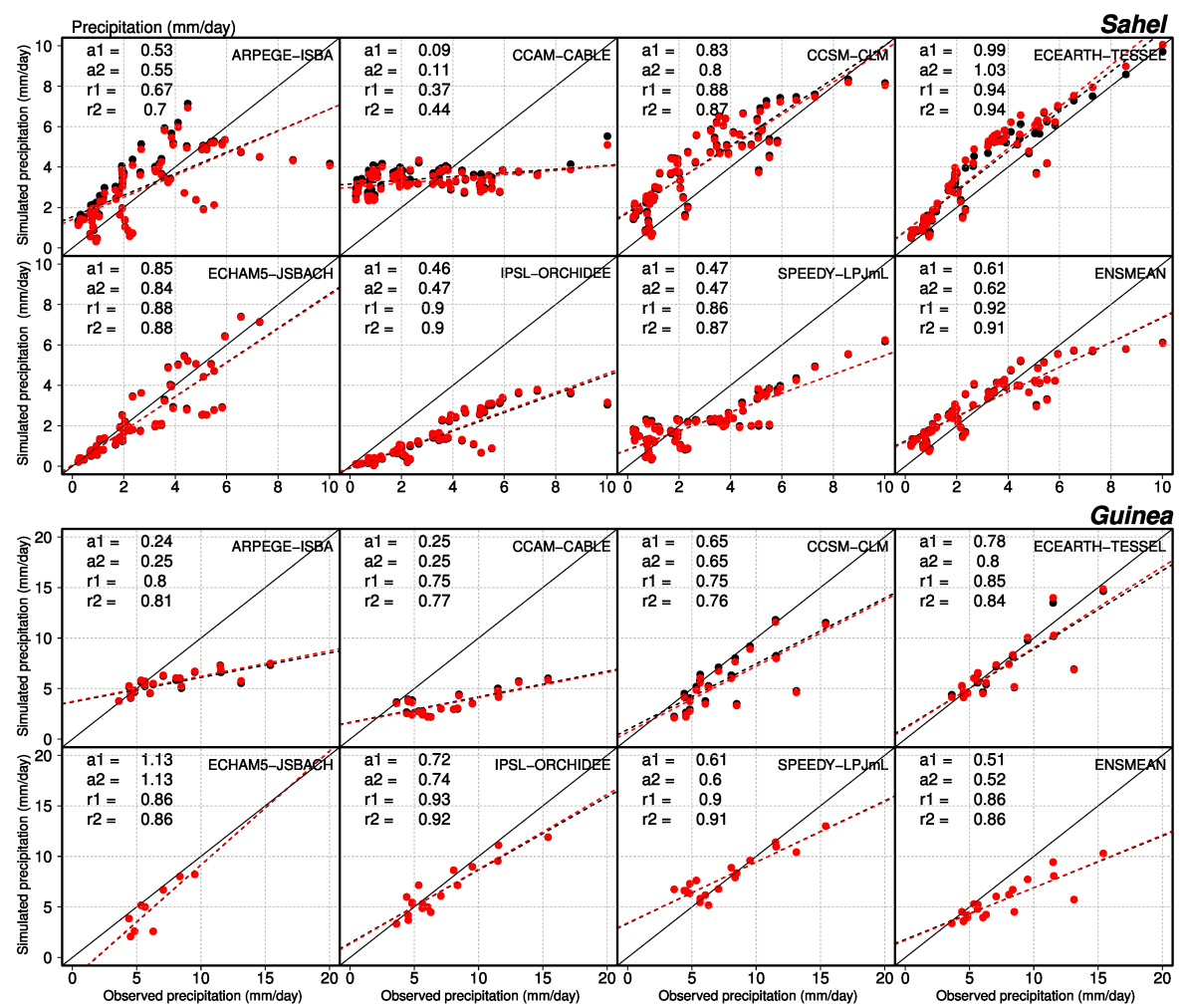

Figure 4. Simulated versus observed summer rainfall at the pixel level. Black and red colors represent $\mathrm{PD}$ and PDv simulations respectively. The slope of the regression line (a1, a2) and spatial correlation $(\mathrm{r} 1, \mathrm{r} 2)$ are shown for PD and PDv simulation respectively.
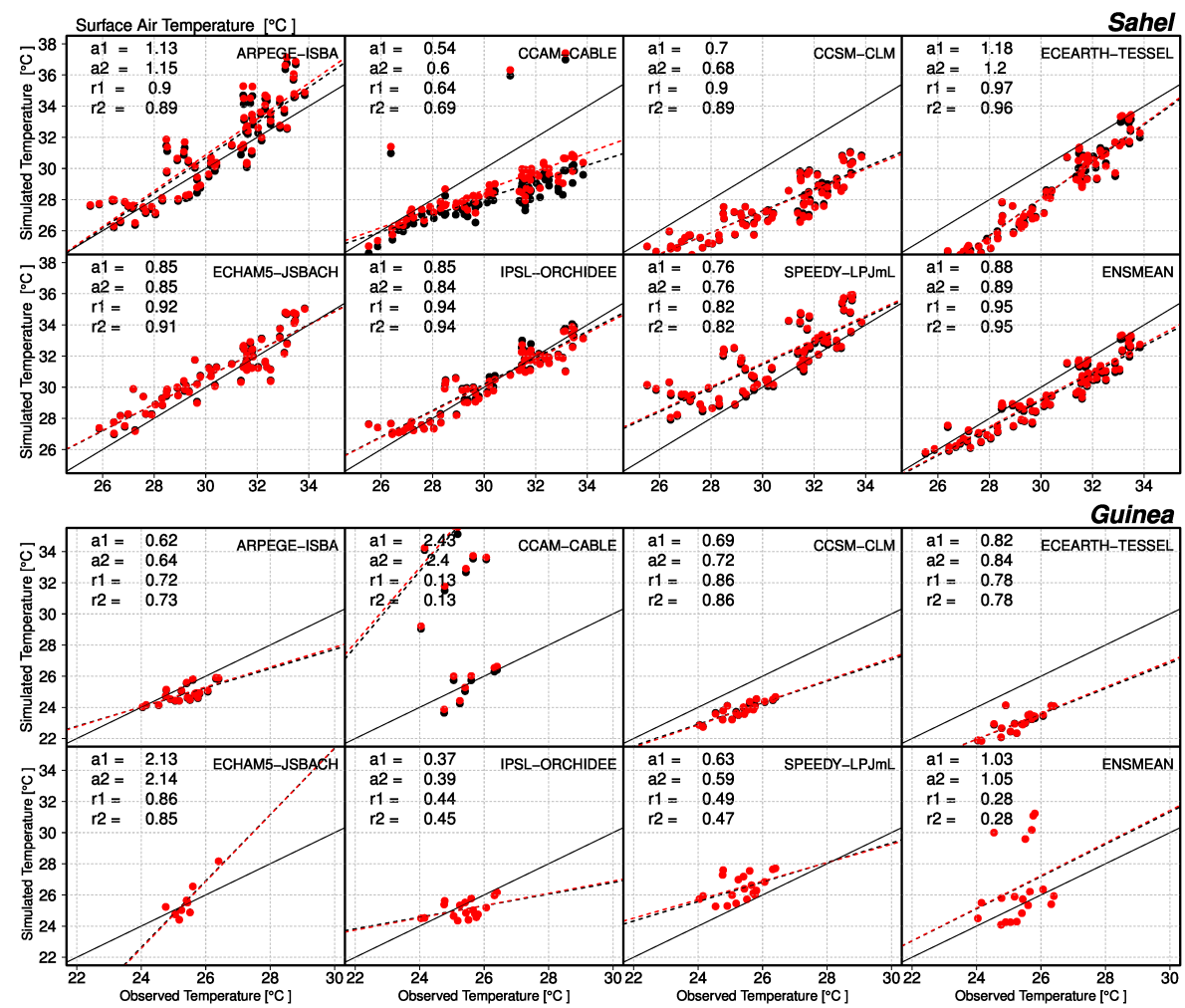

Figure 5. As in Figure 4, but for near surface temperature. 


\subsection{Is Appropriate Land Cover Prescription Improving Model Skill?}

Our simulations allow us to disentangle the role of historical land-cover change on surface climate. Therefore we have compared two simulations of rainfall and surface air temperature, using respectively present-day (PD) and pre-industrial land cover distribution (PDv). If land cover matters in models for surface climate in West Africa, the PD simulation should be closer to (or less far away from) observed precipitation and surface air temperatures than PDv. The small differences shown between PD and PDv simulations (black vs red dots on Figures 4 and 5) with respect to mean 'climatic' rainfall and temperature, implies that changes in land cover did not really improve the representation of these variables. Results from Table 5 further confirm that there is no clear improvement or degradation of the correlations and RSME scores between both PD and PDv simulations for most models.

\subsection{Evaluation of Land Surface Characteristics}

The first land characteristic that is impacted by land cover change is the leaf area index (LAI). LAI is either imposed in climate models as a function of vegetation type (ARPEGE, CCAM, CCSM) or calculated as a function of net primary productivity (IPSL, ECHAM, SPEEDY). This variable impacts surface albedo and surface roughness. Changes in the structure of land surface properties affect the lower atmosphere via the surface energy budget and the surface water budget [74]. Changes in albedo, surface roughness, LAI, root depth and a range of other biophysical characteristics affect the surface energy balance both via changing net radiation and via the partitioning of net radiation between sensible and latent heat [75-77]. A change in the partitioning of net radiation can affect boundary layer depth [78] and thereby clouds and incoming solar radiation [75]. As discussed in Section 2, land-cover changes vary across models. Indeed in the Sahel, some land surface models prescribed a greening between pre-industrial and present time (e.g., ARPEGE, SPEEDY), while others prescribed some deforestation (e.g., IPSL, CCSM, ECEARTH, ECHAM5). These two categories of LSMs will have to be considered separately in the following as they have opposite forcings. However, in the present study we take into account the net response to combined historical LULCC including both afforestation as well as deforestation, while most existing studies favor only one or the other change.

\subsubsection{Evaluation of Present-Day Leaf Area Index in Land Surface Models}

Figure 6 shows seasonal variations of LAI simulated by the LUCID LSMs, together with the ensemble mean and the observed variations in the Sahel and Guinea zones. In the Sahel zone, four out of seven LSM (ARPEGE, CCAM, CCSM and IPSL) correctly reproduce the observed timing of the growing season which is centred in late summer, although the magnitude may not be correct. Three of those models (ARPEGE, CCAM and CCSM) impose their LAI from observations, while IPSL computes it. ECEARTH imposes a fixed value of LAI through time, while SPEEDY displays almost no seasonality in LAI through time. ECHAM5 exhibits a well marked seasonal cycle, with too large and unrealistic LAI values, all being prognostically calculated. In the Guinea zone features are overall the same between models, except for IPSL and ECHAM5 that simulates a more pronounced seasonal cycle than observed with quite larger values at all time. Those results are confirmed in Table 6. The standard deviation represents the inter-annual variability of mean regional summer LAI. All models except ECHAM5 strongly underestimate the observed inter-annual variability. Such feature is quite normal for models that impose a mean climatological LAI (CCAM, ARPEGE, CCSM, ECEARTH). They present no correlation with the observed LAI because they simply have no inter-annual variability. The discrepancies in LAI from one model to another results from the differences in prescribed land cover, but also from differences inherent to the land surface models. For instance, the LAI values imposed to ARPEGE or CCSM do not come from the same database. IPSL and ECHAM5 calculate their LAI as the result of net primary production and allocation processes to various parts of the plants. Those differences in LSMs further enhance the initial differences resulting from the various land cover imposed. 

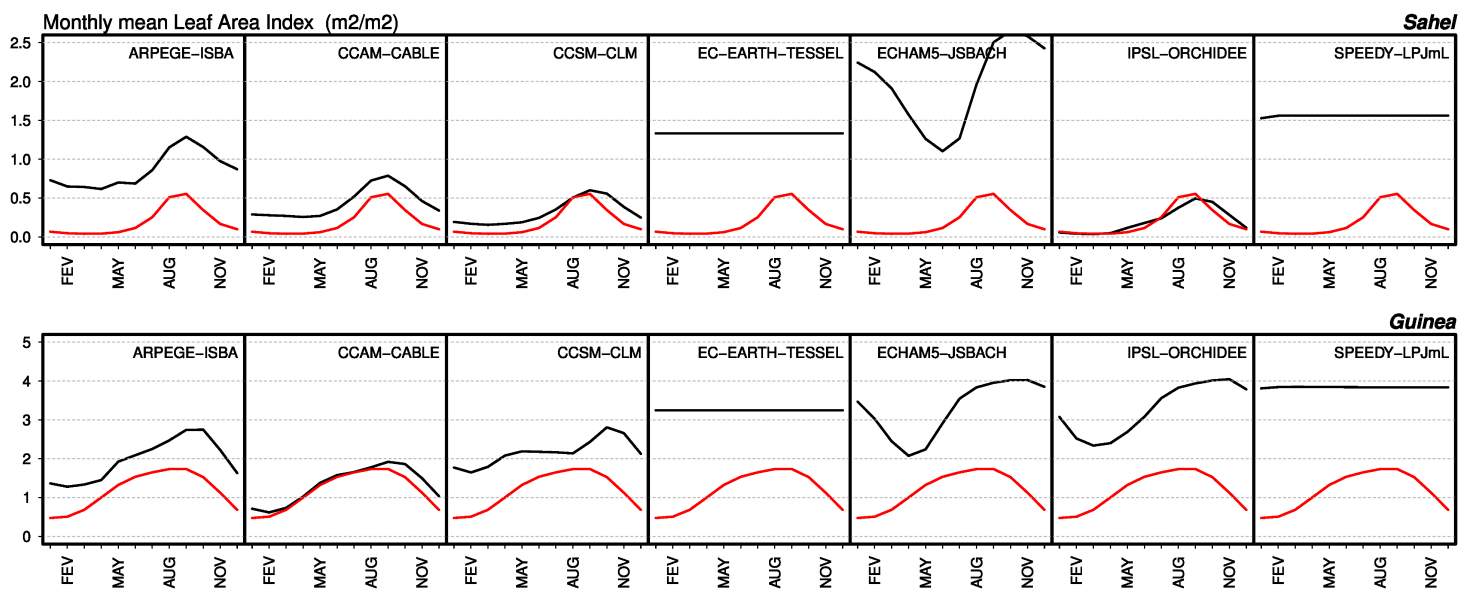

Figure 6. Seasonal variations of present-day leaf area index (LAI) distribution simulated by the models listed at the top of each panel, and by the observation data set in red curve into each panel. Monthly mean of LAI are averaged over the Sahel zone (top) and the Guinea zone (bottom).

Table 6. Correlation between the simulated and observed leaf area index $\left(r_{L A I}\right)$, and Standard deviation $\left(S T D_{L A I}\right)$ in June to September for each of AGCM/LSMs in both regions. The models that impose a mean climatological LAI from satellites observations $\left(S T D_{L A I}=0.0\right)$ are not shown.

\begin{tabular}{cccccc}
\hline \multirow{2}{*}{ GCM/LSMs } & \multicolumn{2}{c}{ Sahel } & & \multicolumn{2}{c}{ Guinea } \\
\cline { 2 - 3 } \cline { 5 - 6 } \cline { 5 - 6 } & $r_{\text {LAI }}$ & $S_{\text {STD }}$ LAII & & $r_{\text {LAI }}$ & $S T D_{\text {LAI }}$ \\
\hline ECHAM5/JSBACH & 0.30 & 0.13 & & 0.31 & 0.17 \\
IPSL/ORCHIDEE & -0.22 & 0.03 & & 0.24 & 0.07 \\
SPEEDY/LPJmL & - & 0.00 & & 0.33 & 0.00 \\
OBS & & 0.05 & & 0.05 \\
\hline
\end{tabular}

\subsubsection{From Land-Cover Change to Changes in Land Surface Characteristics}

The impact of LULCC change on leaf area index are shown on Figure 7 for both regions. The decreasing foliage development results from forests fraction, which has commonly been replaced by crops and grasslands. In the Sahel zone, two LSMs show a decreased LAI in summer. In the Guinea zone, most LSMs (except CABLE and JSBACH) show a decrease in LAI (see Figure 7 above). Increased LAI in summer (JSBACH in the Guinea zone ) can result in a shift of the seasonal cycle of crop leaves (leaf phenology). In the models leaves do not emerge at the same time as tree leaves, and the length of the season is fairly shorter for crops than for most other plant types. It can also result from the growing crops and pastures on the bare soil (for ISBA) or from a larger LAI for crops than for grass when the crops are growing to the detriment of herbaceous (for CABLE).

Figure 8a,b highlights the impact of LULCC on surface albedo. The relationship between changes in LAI and changes in surface albedo varies from model to model, and tends to follow the magnitude of change in LAI that depends on LSM representation and on deforested or anthropized area. However, the increase in surface albedo is simulated for models which extends crops or pastures fraction to the detriment of large deforestation while a decrease is simulated for models which replace crops and pastures fraction for deserts (ISBA). Surface albedo does not change for models which mix crops and grasses in grid cells (CABLE). In this version of CABLE, the parameters used to calculating canopy albedo do not vary as a function of plant functional type [75], making the model albedo insensitive to changes in vegetation structure (this has been revised in a more recent version of the model). In the Sahel zone, small changes to surface albedo, e.g., $+0.5 \%$, are simulated by the models for which small changes in LULCC are prescribed. In the Guinea zone, albedo changes are roughly proportional to the deforestation with a small change in surface albedo $(+1 \%)$ for six models except the CCAM model. These small responses in surface albedo to LULCC simulated by the models can be partly attributed 
to the underestimating LULCC between 1992 and 1870 as discussed in Section 2.3. Except CABLE in the Guinean zone, all LSMs simulate a decrease in surface roughness especially given the deforested fraction which is prescribed (Figure $8 c, d$ ). Changes in surface roughness magnitude are related to the magnitude of deforestation, with a decrease of about $10-15 \%$ corresponding to an almost complete forest clearance in summer. In the Sahel zone, only two out of seven LSMs (TESSEL and ORCHIDEE) prescribed deforestation and simulate a decrease in the length of surface roughness. In summary, models show a clear link between changes in LAI, in surface roughness and surface albedo.

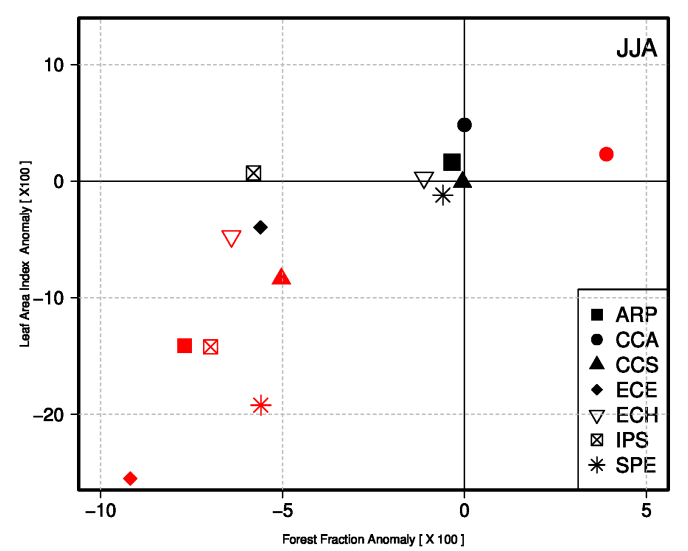

Figure 7. Summer LULCC-induced anomaly in the simulated leaf area index in (\%) plotted against the anomaly the anomaly in forest fraction between PD and PI times. Symbols refer to the various models used (ARP: ARPEGE-ISBA; CCA: CCAM-CABLE; CCS: CSSM-CLM; ECE: ECEARTH-TESSEL; ECH: ECHAM5-JSBACH; IPS: IPSL-ORCHIDEE; SPE: SPEEDY-LPJmL). Red symbols refer to the Guinea zone, while black symbols refer to the Sahel zone.
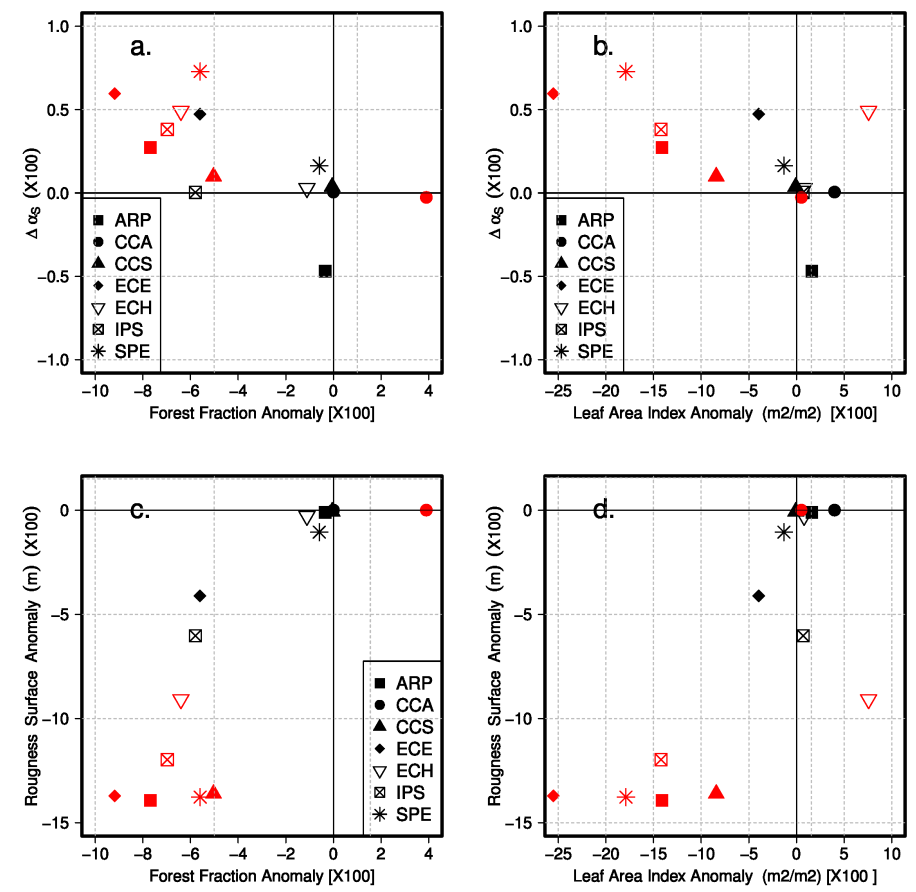

Figure 8. Summer LULCC-induced anomaly in the simulated surface albedo (\%) plotted against the anomaly in forest fraction (a) and the anomaly in leaf area index (b); Surface roughness (\%) plotted against the anomaly in forest fraction (c) and the anomaly in leaf area index (d) between PD and PI times. Symbols refer to the various models as illustrated in Figure 2. Red symbols are for the Guinea zone, while black symbols are for the Sahel zone in summer (JJA). 


\section{Discussion}

\subsection{Interactions between LAI and Surface Climate}

Results in Section 3.2 discussed the relationship between LAI and both surface albedo and surface roughness. Surface albedo and roughness are two important surface variables that influence net radiation and turbulent fluxes, and therefore surface temperature and the amount of water vapor transferred to the atmosphere. Figure 9 shows the correlation between LAI and precipitation on the one hand and the correlation between LAI and surface air temperature on the other hand for both models and observations. Observations show that precipitation is highly and positively correlated to foliage density with values larger or equal to 0.8 in both the Sahel and Guinea zones. This implies that the larger the LAI is, the larger the rainfall is. Five out of seven models also show positive correlations, but not as large as observed correlations. None of the models is able to reproduce large correlation between Precipitation and LAI in the Guinea zone. The ECHAM5 climate model is simulating an inverse (e.g., negative) relationship between LAI and rainfall in the Sahel zone. However, those relationships are very small and non significant for both regions. ECEARTH is showing no correlation by construction, because its LAI does not vary through time. The correlation between LAI and surface air temperature is positive in the Sahel zone and negative in the Guinea zone. This suggests that an increased LAI in Guinea will result to increased evapotranspiration and therefore a cooler surface, while in the Sahel zone the albedo effect of increased LAI may dominate and lead to increased surface temperature. The correlation is quite small in the Sahel zone $(\sim 0.15)$ and quite large in the Guinea zone ( -0.5). Only three models out of seven capture this dual signal: ARPEGE, CCSM and IPSL. Among those three models, only two show larger correlation in the Guinea zone than in the Sahel zone, as observed (ARPEGE and IPSL) although they also tend to overestimate both correlations. Those models also have the best representation of seasonal LAI. ECHAM5 is systematically showing a negative correlation between temperature and LAI, while CCAM is showing an opposite relationship to the observed, but this is quite small and therefore negligible.
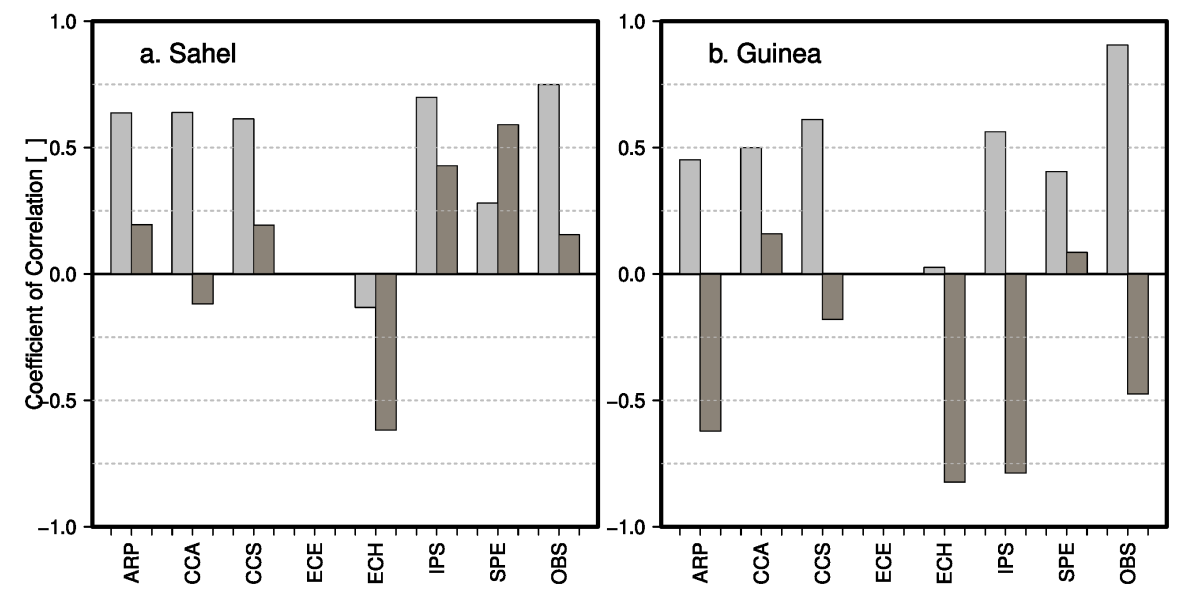

Figure 9. Pearson correlation coefficients between monthly simulated precipitation and leaf area index (Light gray), together with the correlation between monthly simulated near surface temperature and leaf area index (Dark gray), for each of seven climate models and for observation data-set in both regions defined in the Sahel (a) and the Guinea zones (b). Simulated and observed times series (1982-1999) were linearly detrended before calculated pearson correlation coefficient.

Our results have two implications that can to be derived from Figure 9:

1. LAI needs to be thoroughly evaluated in all land surface models, especially when they are coupled to their host climate model. The importance of evaluation in a coupled mode has already been stressed by e.g., Boisier and Quesada et al. [21,79] for the temperate latitudes, and this is of 
crucial importance in West Africa as both precipitation and surface air temperature are correlated to the greenness index of the land surface;

2. the coupling intensity between land and atmosphere varies strongly from one model to another. ECHAM5 for example is showing a stronger coupling between surface temperature and LAI with respect to rainfall and LAI, while the reverse is obtained from simulations. The importance of a proper evaluation of coupling strength in climate models has already been stressed by other authors (e.g., $[26,79,80])$.

\subsection{The Respective Roles of Historical Land Cover Changes and Atmospheric $\mathrm{CO}_{2}$}

We compared the simulated regional climate changes induced by LULCC to the ones induced by CO2SST. Figure 10 illustrates the changes in surface air temperature, precipitation and water recycling. Water recycling is expressed by evapotranspiration and precipitation ratio $(\mathrm{E} / \mathrm{P})$ for all climate models and for each season. The changes of CO2SST lead to an increase in available energy at the surface (2-5 $\mathrm{Wm}^{-2}$ in the Sahel zone) and (5-10 $\mathrm{Wm}^{-2}$ in the Guinea zone) (not shown) with larger values simulated during summer when incoming radiation is at its peak. This increase is mainly caused by increased incoming infrared radiation $Q_{L D}$ associated with the higher atmospheric concentration in $\mathrm{CO}_{2}$. This increased $Q_{A}$ is associated with a surface warming of $0.2-0.6^{\circ} \mathrm{C}$ in the Sahel and $0.6-0.7^{\circ} \mathrm{C}$ in the Guinea zone (Figure 10a,b) for all seasons with slightly larger values during summer particularly in the Sahel zone. In contrast to the Guinea zone, there is little seasonal variation of the climatic response to $\mathrm{CO}_{2}$.
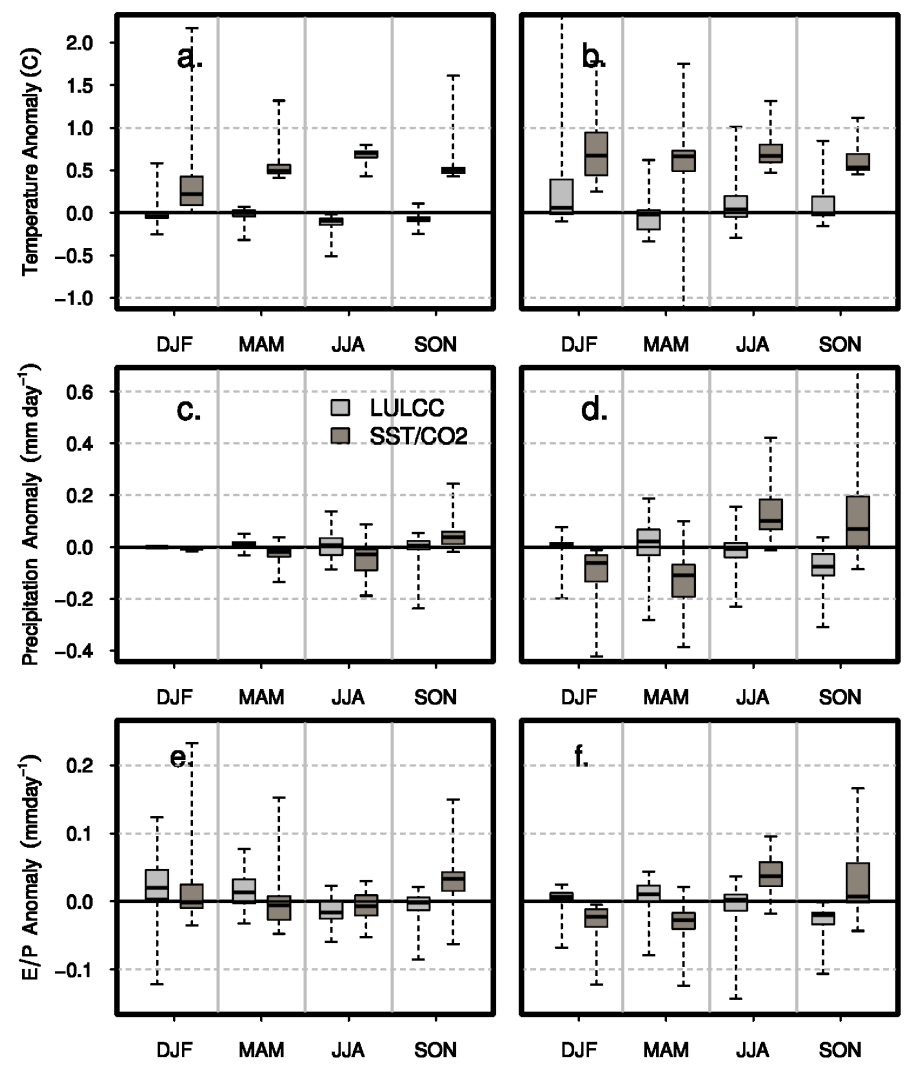

Figure 10. Simulated anomaly in $(\mathbf{a}, \mathbf{b})$ surface air temperature; $(\mathbf{c}, \mathbf{d})$ Precipitation and $(\mathbf{e}, \mathbf{f})$ water recycling (expressed by $\mathrm{E} / \mathrm{P}$ ) induced by LULCC (light gray) and by changes in CO2SST (dark gray boxes). Differences are calculated between the present day and preindustrial period. The anomalies are calculated for each grid cell in the two regions defined in Sahel $(\mathbf{a}, \mathbf{c}, \mathbf{e})$ and Guinea $(\mathbf{b}, \mathbf{d}, \mathbf{f})$. Box-whisker plots indicate the extremes, the inter-quartile range (5th and 95th percentiles), and the median of the mean ensemble values of each individual model and each set of experiment (PD-PDv for the LULCC impacts, PD-PIv for CO2SST impacts). 
In contrast, LULCC induced biophysical effects lead to slightly cooler surfaces (and decrease in $Q_{A}$ ) in the Sahel zone. In the Guinea zone, the response to LULCC is small but the spread between the models'responses is larger. The reason for this large spread across models has been discussed in former LUCID studies (see [21,22]). In autumn in the Guinea zone, there is a significant decrease in precipitation of about $-0.07 \mathrm{~mm} /$ day which is associated with a significant reduction in the intensity of water recycling of about $-0.05 \mathrm{~mm} /$ day due to historical LULCC (Figure 10d,f). In Summer in the Sahel zone, LULCC has a similar impact as CO2SST on decreased water recycling but it does not significantly affect change in precipitation (Figures 10c and 11b). The decreased water recycling in the Sahel zone in response to LULCC might be related to the reduction in evapotranspiration of moisture from soil and vegetation, when forests are replaced by crops or pasture [81].

In summary, models show that surface climate in the western Sahel has been more influenced by the increase in greenhouse gases since pre-industrial times, and by its consequences on sea-surface temperatures than by LULCC impact in summer (Figure 11a). In other terms, the significant summer cooling in Western Sahel in response to LULCC tend to cool the surface and thus counteract the surface warming induced by CO2SST.

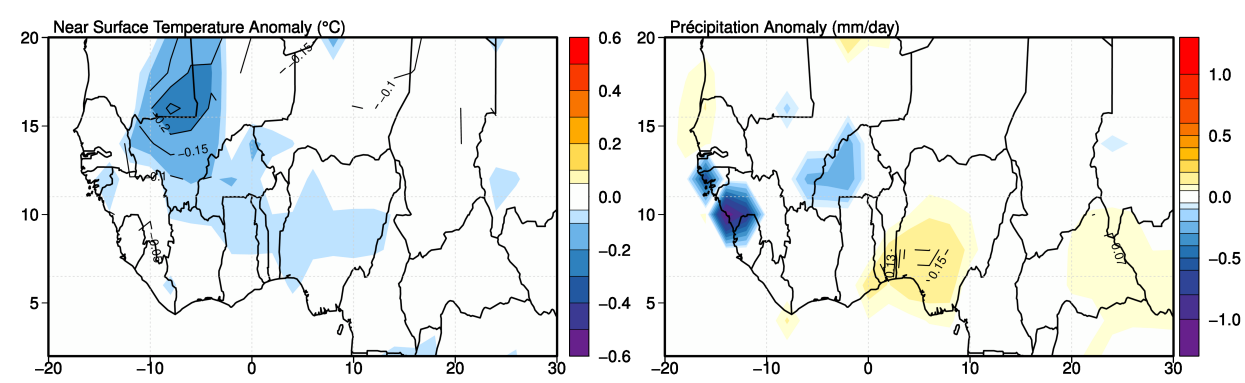

Figure 11. Temperature and rainfall response to biophysical effects of historical LULCC (ENSMEAN over boreal summer). Only continental grid points where at-least $70 \%$ of the seven climate models (e.g., 5/7 models) agree on the sign of change are displayed. The black contours depict regions where at least $70 \%$ of the seven climate models have similar anomaly, and the ensemble mean is significant at the 0.05 level with a $t$-test.

\subsection{Underlying Physical Mechanisms Controlling LULCC-Induces Changes in Surface Climate}

To improve the understanding of the underlying physical mechanisms that control changes in surface climate, Figure 12 shows the sensitivity of surface temperature changes to main components of the surface energy balance in the Sahel zone (Figure 12a) and the Guinea zone (Figure 12b). We particularly focus on the relative contribution of the "atmospheric feedback" (e.g., changes in incoming solar and longwave radiation, dots and linear regression in blue), the "solar reflection" (e.g., upward minus downward solar incoming radiation, in green) and the "turbulent heat fluxes" (e.g., sum of latent and sensible heat flux, in red), for seasonal temperature in the two regions. Surface temperature changes are positively and significantly influenced by an indirect LULCC-effect implying change in total incoming radiation (e.g., changes in cloud cover, humidity and/or remote effects), with correlations of +0.4 and +0.53 respectively for the Sahel and Guinea zones (Figure 12, blue symbols). For the Sahel zone, decreases in solar reflection tend to cool down the surface and thus counteract the atmospheric feedback effect while changes in turbulent heat fluxes tend to have a minor effect on temperature. Those two effects can further explain the relative cooling induced by LULCC in the Sahel zone (Figure 12a). In other terms, the significant summer cooling in Western Sahel in response to LULCC (up to $-0.25^{\circ} \mathrm{K}$ ), seem to be mostly albedo-driven (direct effect) in combination with changes in incoming radiation that originate from local or remote regions (indirect effect).

In contrast, in the Guinea zone, the physical mechanism implying "turbulent heat fluxes" tend to be positively correlated with changes in temperature e.g., more turbulent heat fluxes tend to be correlated with higher surface temperatures. This can be interpreted as two competitive effects at 
work: LULCC induce more total incoming radiation (in line with less cloud cover) that is in return transferred to the atmosphere by an increase in turbulent heat fluxes (particularly sensible heat flux, due to a decreased forest cover ) without significant changes in temperature.
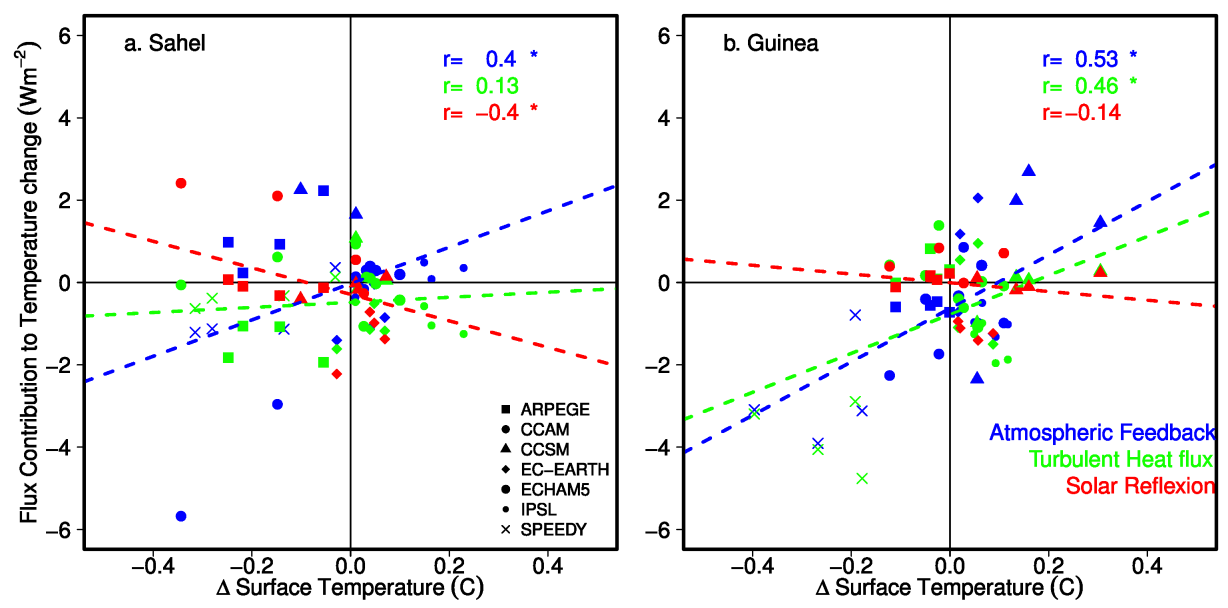

Figure 12. Fluxes contribution $\left(\mathrm{Wm}^{-2}\right)$ to surface temperature changes $\left({ }^{\circ} \mathrm{C}\right)$. For each model (seven different symbols), each season (DJF, MAM, JJA, and SON) and each region (Sahel (a) and Guinea (b)), the relation between temperature changes ( $x$ axis) versus $\Delta Q_{S D}+\Delta Q_{L D}-(1)$ "atmospheric feedback" in blue, $\Delta Q_{S U}-\Delta Q_{S D}$-(2) solar reflection in red, and $\Delta Q_{L E}+\Delta Q_{H}$-(3) Turbulent heat fluxes in green, is drawn ( $y$ axis). Linear trends and corresponding Pearson correlation coefficients values (r) are added for each contribution. A star symbol is added when the correlation is significant $(p<0.05)$.

\section{Conclusions}

Our simulations allow us to investigate the biophysical effects of historical land-cover change on surface climate in West Africa. In this study, we aimed to develop a wide multimodel climate picture of biophysical effects in response to a "reasonable" historic LULCC scenario in West Africa. Conversely to many studies investigating LULCC impacts with one model solely or one idealized regional land cover change scenario [82,83], we investigated an ensemble of models which allowed to further explore uncertainties and the various mechanisms at play. The biophysical climate responses represent the most likely climatic impacts of a plausible historical LULCC scenario applied to seven different LSMs. These LSMs have different interpretation of land use classes resulting from: (i) the way LULCC information is represented in models; (ii) the strategy used by each modeling group to implement LULCC in their background land cover; and (iii) the usage of different sources of information to describe present-day or potential vegetation by the modeling groups. This study disentangles result differences among models, for two contrasted African regions (the Sahel and Guinea zones), and it also investigates the sensitivity of climate models to LULCC intensity, bringing more physical elements to explain simulated biophysical changes. We found that climate responses of land-use changes are small in West Africa but statistically significant. In summer, we found that models simulate a significant near-surface atmospheric cooling, a significant weakening of water recycling in the Western Sahel in response to historical LULCC. In the Guinea zone, models simulate significant changes in precipitation and water recycling in autumn in response to LULCC. These changes are comparable in magnitude with those resulting from increased greenhouse gases concentration since pre-industrial times. This result implies that LULCC is an important factor to take into account in climatic assessments. However the small responses of the seven climate models to LULCC in West Africa are attributed in our study to: (i) the prescribed LULCC that can be underestimated in those regions; (ii) the climate models tending to underestimate the coupling strength between West African surface climate (precipitation and temperature) and leaf area index (LAI) and (iii) the lack of interactive 
LAI in some models i.e., have no amplification/feedback effect. These results highlight the need for improved multimodel experiments in order to progress on the understanding of LULCC in West Africa, and for further improvement of simulation of the West African Monsoon. Finally, our study reveals significant indirect atmospheric processes triggered by LULCC for both studied regions, implying substantial changes in incoming and longwave radiation. In Western Sahel, models reveal significant decreases in solar reflection that tend to cool the surface and thus counteract the atmospheric feedback. In contrast to the Guinea zone, models reveal that the physical mechanism implying "turbulent heat fluxes" and that indirect "atmospheric processes" dominate climatic responses over the direct effects of LULCC. Our findings contribute to the understanding of the physical mechanisms triggered by LULCC in West Africa region and show that climate models are able to simulate significant climate perturbations in response to LULCC albeit underestimated. Thus, our results also suggest that further research is needed to improve our understanding of the physical mechanisms driving the indirect atmospheric cooling processes in West Africa. These effects are not apparent in the LUCID simulations. Furthermore, this study represents an alert for the scientific community because LULCC forcing can substantially differ among climate models. We recommend that in future multimodel risk assessment, scientists take into account and assess the relative importance of direct and indirect biophysical effects of LULCC.

Acknowledgments: This work is a contribution to the complex modeling systems program PDI-MSC. This investigation was supported by funding from IRD and Université Pierre et Marie Curie (UPMC). The authors are grateful to the gouvernment of Grand-Duche of Luxembourg through the Reference Office in Climate Change of the Centre de Suivi Ecologique and for LMI-ECLAIRS project for facilitating travel from Dakar to Paris, which permitted stronger interactions between the principal investigators of this study. The authors are also grateful to all LUCID participants for providing modeling data as well as for the anonymous reviewers and the academic editor for their constructive comments.

Author Contributions: Souleymane Sy, Nathalie de Noblet-Ducoudré and Benjamin Quesada prepared the manuscript, collected the data as well as data processing and analysis. Amadou Thierno Gaye and Benjamin Sultan has realised the validation. Ibrahima Sy and Amadou Moctar Dieye contributed to the discussion.

Conflicts of Interest: The authors declare no conflict of interest.

\section{References}

1. Ramankutty, N.; Foley, J.A. Estimating historical changes in global land cover: Croplands from 1700 to 1992. Glob. Biogeochem. Cycles 1999, 13, 997-1027.

2. DeFries, R.; Hansen, M.; Townshend, J. Global discrimination of land cover types from metrics derived from AVHRR pathfinder data. Remote Sens. Environ. 1995, 54, 209-222.

3. Goldewijk, K.K. Estimating global land use change over the past 300 years: The HYDE database. Glob. Biogeochem. Cycles 2001, 15, 417-433.

4. Hurtt, G.; Frolking, S.; Fearon, M.; Moore, B.; Shevliakova, E.; Malyshev, S.; Pacala, S.; Houghton, R. The underpinnings of land-use history: Three centuries of global gridded land-use transitions, wood-harvest activity, and resulting secondary lands. Glob. Chang. Biol. 2006, 12, 1208-1229.

5. Pongratz, J.; Reick, C.; Raddatz, T.; Claussen, M. A reconstruction of global agricultural areas and land cover for the last millennium. Glob. Biogeochem. Cycles 2008, 22, doi:10.1029/2007GB003153.

6. Kaplan, J.O.; Krumhardt, K.M.; Ellis, E.C.; Ruddiman, W.F.; Lemmen, C.; Goldewijk, K.K. Holocene carbon emissions as a result of anthropogenic land cover change. Holocene 2010, 21, 775-791.

7. Klein Goldewijk, K.; Beusen, A.; Van Drecht, G.; De Vos, M. The HYDE 3.1 spatially explicit database of human-induced global land-use change over the past 12,000 years. Glob. Ecol. Biogeogr. 2011, 20, 73-86.

8. Hurtt, G.; Chini, L.P.; Frolking, S.; Betts, R.; Feddema, J.; Fischer, G.; Fisk, J.; Hibbard, K.; Houghton, R.; Janetos, A.; et al. Harmonization of land-use scenarios for the period 1500-2100: 600 years of global gridded annual land-use transitions, wood harvest, and resulting secondary lands. Clim. Chang. 2011, 109, 117-161.

9. Brovkin, V.; Boysen, L.; Arora, V.K.; Boisier, J.P.; Cadule, P.; Chini, L.; Claussen, M.; Friedlingstein, P.; Gayler, V.; Van Den Hurk, B.; et al. Effect of anthropogenic land-use and land-cover changes on climate and land carbon storage in CMIP5 projections for the twenty-first century. J. Clim. 2013, 26, 6859-6881. 
10. Scanlon, B.R.; Jolly, I.; Sophocleous, M.; Zhang, L. Global impacts of conversions from natural to agricultural ecosystems on water resources: Quantity versus quality. Water Resour. Res. 2007, 43, doi:10.1029/2006WR005486.

11. Warburton, M.L.; Schulze, R.E.; Jewitt, G.P. Hydrological impacts of land use change in three diverse South African catchments. J. Hydrol. 2012, 414, 118-135.

12. Pitman, A.J.; de Noblet-Ducoudré, N.; Cruz, F.T.; Davin, E.L.; Bonan, G.B.; Brovkin, V.; Claussen, M.; Delire, C.; Ganzeveld, L.; Gayler, V.; et al. Uncertainties in climate responses to past land cover change: First results from the LUCID intercomparison study. Geophys. Res. Lett. 2009, 36, L14814.

13. De Noblet-Ducoudré, N.; Boisier, J.P.; Pitman, A.; Bonan, G.B.; Brovkin, V.; Cruz, F.; Delire, C.; Gayler, V.; van den Hurk, B.J.J.M.; Lawrence, P.J.; et al. Determining robust impacts of land-use-induced land cover changes on surface climate over North America and Eurasia: Results from the first set of LUCID experiments. J. Clim. 2012, 25, 3261-3281.

14. Tilman, D.; Fargione, J.; Wolff, B.; D'Antonio, C.; Dobson, A.; Howarth, R.; Schindler, D.; Schlesinger, W.H.; Simberloff, D.; Swackhamer, D. Forecasting agriculturally driven global environmental change. Science 2001, 292, 281-284.

15. Bonan, G.B. Forests and climate change: Forcings, feedbacks, and the climate benefits of forests. Science 2008, 320, 1444-1449.

16. Chase, T.; Pielke, R., Sr; Kittel, T.; Nemani, R.; Running, S. Simulated impacts of historical land cover changes on global climate in northern winter. Clim. Dyn. 2000, 16, 93-105.

17. Werth, D.; Avissar, R. The local and global effects of Amazon deforestation. J. Geophys. Res. 2002, 107, LBA 55-1-LBA 55-8.

18. Koster, R.D. Regions of strong coupling between soil moisture and precipitation. Science 2004, 305, 1138-1140.

19. Findell, K.L.; Knutson, T.R.; Milly, P. Weak simulated extratropical responses to complete tropical deforestation. J. Clim. 2006, 19, 2835-2850.

20. Seneviratne, S.I.; Lüthi, D.; Litschi, M.; Schär, C. Land-atmosphere coupling and climate change in Europe. Nature 2006, 443, 205-209.

21. Boisier, J.P.; de Noblet-Ducoudré, N.; Pitman, A.J.; Cruz, F.T.; Delire, C.; van den Hurk, B.J.J.M.; van der Molen, M.K.; Müller, C.; Voldoire, A. Attributing the impacts of land-cover changes in temperate regions on surface temperature and heat fluxes to specific causes: Results from the first LUCID set of simulations: Biogeophysical impacts of LULCC. J. Geophys. Res. 2012, 117, doi:10.1029/2011JD017106

22. Boisier, J.P.; de Noblet-Ducoudré, N.; Ciais, P. Inferring past land use-induced changes in surface albedo from satellite observations: A useful tool to evaluate model simulations. Biogeosciences 2013, 10, 1501-1516.

23. Nicholson, S.E. The West African Sahel: A review of recent studies on the rainfall regime and its interannual variability. ISRN Meteorol. 2013, 2013, 453521.

24. Redelsperger, J.L.; Thorncroft, C.D.; Diedhiou, A.; Lebel, T.; Parker, D.J.; Polcher, J. African Monsoon Multidisciplinary Analysis: An international research project and field campaign. Bull. Am. Meteorol. Soc. 2006, 87, 1739-1746.

25. Taylor, C.M.; Parker, D.J.; Kalthoff, N.; Gaertner, M.A.; Philippon, N.; Bastin, S.; Harris, P.P.; Boone, A.; Guichard, F.; Agusti-Panareda, A.; et al. New perspectives on land-atmosphere feedbacks from the African Monsoon Multidisciplinary Analysis. Atmos. Sci. Lett. 2011, 12, 38-44.

26. Koster, R.D.; Sud, Y.; Guo, Z.; Dirmeyer, P.A.; Bonan, G.; Oleson, K.W.; Chan, E.; Verseghy, D.; Cox, P.; Davies, H.; et al. GLACE: The global land-atmosphere coupling experiment. Part I: Overview. J. Hydrometeorol. 2006, 7, 590-610.

27. Dirmeyer, P.A. The terrestrial segment of soil moisture-climate coupling. Geophys. Res. Lett. 2011, 38, doi:10.1029/2011GL048268.

28. Eltahir, E.A.; Gong, C. Dynamics of wet and dry years in West Africa. J. Clim. 1996, 9, 1030-1042.

29. Xue, Y.; Boone, A.; Taylor, C.M. Review of recent developments and the future prospective in West African atmosphere/land interaction studies. Int. J. Geophys. 2012, 2012, 748921.

30. Charney, J.G. Dynamics of deserts and drought in the Sahel. Q. J. R. Meteorol. Soc. 1975, 101, $193-202$.

31. Sud, Y.; Fennessy, M. A study of the influence of surface albedo on July circulation in semi-arid regions using the glas GCM. J. Climatol. 1982, 2, 105-125.

32. Laval, K.; Picon, L. Effect of a change of the surface albedo of the Sahel on climate. J. Atmos. Sci. 1986, 43, 2418-2429. 
33. Xue, Y.; Shukla, J. The influence of land surface properties on Sahel climate. Part II. Afforestation. J. Clim. 1996, 9, 3260-3275.

34. Xue, Y.; Juang, H.M.; Li, W.P.; Prince, S.; DeFries, R.; Jiao, Y.; Vasic, R. Role of land surface processes in monsoon development: East Asia and West Africa. J. Geophys. Res. 2004, 109, D03105.

35. Li, X.; Kong, D.; Tan, H.; Wang, X. Changes in soil and vegetation following stabilisation of dunes in the southeastern fringe of the Tengger Desert, China. Plant Soil 2007, 300, 221-231.

36. Walker, J.; Rowntree, P. The effect of soil moisture on circulation and rainfall in a tropical model. Q. J. R. Meteorol. Soc. 1977, 103, 29-46.

37. Cunnington, W.; Rowntree, P. Simulations of the Saharan atmosphere-dependence on moisture and albedo. Q. J. R. Meteorol. Soc. 1986, 112, 971-999.

38. Zeng, N.; Neelin, J.D.; Lau, K.M.; Tucker, C.J. Enhancement of interdecadal climate variability in the Sahel by vegetation interaction. Science 1999, 286, 1537-1540.

39. Douville, H.; Chauvin, F.; Broqua, H. Influence of soil moisture on the Asian and African monsoons. Part I: Mean monsoon and daily precipitation. J. Clim. 2001, 14, 2381-2403.

40. Taylor, C.M.; Parker, D.J.; Harris, P.P. An observational case study of mesoscale atmospheric circulations induced by soil moisture. Geophys. Res. Lett. 2007, 34, L15801.

41. Xue, Y.; De Sales, F.; Lau, W.M.; Boone, A.; Feng, J.; Dirmeyer, P.; Guo, Z.; Kim, K.M.; Kitoh, A.; Kumar, V.; et al. Intercomparison and analyses of the climatology of the West African Monsoon in the West African Monsoon Modeling and Evaluation project (WAMME) first model intercomparison experiment. Clim. Dyn. 2010, 35, 3-27.

42. Xue, Y.; De Sales, F.; Lau, W.K.M.; Boone, A.; Kim, K.M.; Mechoso, C.R.; Wang, G.; Kucharski, F.; Schiro, K.; Hosaka, M.; et al. West African monsoon decadal variability and surface-related forcings: Second West African Monsoon Modeling and Evaluation project experiment (WAMME II). Clim. Dyn. 2016, 47, 3517-3545.

43. Boone, A.A.; Xue, Y.; De Sales, F.; Comer, R.E.; Hagos, S.; Mahanama, S.; Schiro, K.; Song, G.; Wang, G.; $\mathrm{Li}, \mathrm{S}$.; et al. The regional impact of Land-Use Land-cover Change (LULCC) over West Africa from an ensemble of global climate models under the auspices of the WAMME2 project. Clim. Dyn. 2016, 47, 3547-3573.

44. Pielke, R.A.; Pitman, A.; Niyogi, D.; Mahmood, R.; McAlpine, C.; Hossain, F.; Goldewijk, K.K.; Nair, U.; Betts, R.; Fall, S.; et al. Land use/land cover changes and climate: Modeling analysis and observational evidence. Wiley Interdiscip. Rev. 2011, 2, 828-850.

45. Mahmood, R.; Pielke, R.A.; Hubbard, K.G.; Niyogi, D.; Dirmeyer, P.A.; McAlpine, C.; Carleton, A.M.; Hale, R.; Gameda, S.; Beltrán-Przekurat, A.; et al. Land cover changes and their biogeophysical effects on climate. Int. J. Climatol. 2014, 34, 929-953.

46. Lawrence, D.; Vandecar, K. Effects of tropical deforestation on climate and agriculture. Nat. Clim. Chang. 2015, 5, 27-36.

47. Rayner, N.; Parker, D.E.; Horton, E.; Folland, C.; Alexander, L.; Rowell, D.; Kent, E.; Kaplan, A. Global analyses of sea surface temperature, sea ice, and night marine air temperature since the late nineteenth century. J. Geophys. Res. 2003, 108, doi:10.1029/2002JD002670.

48. Ramankutty, N.; Foley, J.A. Characterizing patterns of global land use: An analysis of global croplands data. Glob. Biogeochem. Cycles 1998, 12, 667-686.

49. Ramankutty, N.; Evan, A.T.; Monfreda, C.; Foley, J.A. Farming the planet: 1. Geographic distribution of global agricultural lands in the year 2000: Global agricultural lands in 2000. Glob. Biogeochem. Cycles 2008, 22, doi:10.1029/2007GB002952.

50. Solomon. Report from the IMAGE 2 Advisory Board Meeting in Amsterdam 20-22 June 1994; Nature Research Progress on Global Air Pollution and Climate Change: Bilthoven, The Netherlands, 1994; pp. 00-13.

51. Salas-Mélia, D.; Chauvin, F.; Déqué, M.; Douville, H.; Gueremy, J.; Marquet, P.; Planton, S.; Royer, J.; Tyteca, S. Description and validation of the CNRM-CM3 global coupled model. Clim. Dyn. 2005, 103, 1-36.

52. McGregor, J.L.; Dix, M.R. An updated description of the conformal-cubic atmospheric model. In High Resolution Numerical Modelling of the Atmosphere and Ocean; Springer: New York, NY, USA, 2008; pp. 51-75.

53. Collins, W.D.; Bitz, C.M.; Blackmon, M.L.; Bonan, G.B.; Bretherton, C.S.; Carton, J.A.; Chang, P.; Doney, S.C.; Hack, J.J.; Henderson, T.B.; et al. The community climate system model version 3 (CCSM3). J. Clim. 2006, 19, 2122-2143. 
54. Roeckner, E. The Atmospheric General Circulation Model ECHAM5. Part I: Model Description; Max Planck Institute for Meteorology Report; Max Planck Institute for Meteorology: Hamburg, Germany, 2003; Volume 349, p. 127.

55. Marti, O.; Braconnot, P.; Bellier, J.; Benshila, R.; Bony, S.; Brockmann, P.; Cadule, P.; Caubel, A.; Denvil, S.; Dufresne, J.; et al. The New IPSL Climate System Model: IPSL-CM4; In Note du Pôle de Modélisation; Institut Pierre Simon Laplace: Paris, France, 2005; Volume 26, pp. 1-86.

56. Strengers, B.J.; Müller, C.; Schaeffer, M.; Haarsma, R.J.; Severijns, C.; Gerten, D.; Schaphoff, S.; van den Houdt, R.; Oostenrijk, R. Assessing 20th century climate-vegetation feedbacks of land-use change and natural vegetation dynamics in a fully coupled vegetation-climate model. Int. J. Climatol. 2010, 30, 2055-2065.

57. Voldoire, A. Quantifying the impact of future land-use changes against increases in GHG concentrations. Geophys. Res. Lett. 2006, 33, L04701.

58. Wang, K.; Li, M.; Hadley, D.; Liu, R.; Glessner, J.; Grant, S.F.; Hakonarson, H.; Bucan, M. PennCNV: An integrated hidden Markov model designed for high-resolution copy number variation detection in whole-genome SNP genotyping data. Genome Res. 2007, 17, 1665-1674.

59. Oleson, K.; Niu, G.Y.; Yang, Z.L.; Lawrence, D.; Thornton, P.; Lawrence, P.; Stöckli, R.; Dickinson, R.; Bonan, G.; Levis, S.; et al. Improvements to the Community Land Model and their impact on the hydrological cycle. J. Geophys. Res. 2008, 113, doi:10.1029/2007JG000563.

60. Van den Hurk, B.J.; Viterbo, P.; Beljaars, A.; Betts, A. Offline Validation of the ERA40 Surface Scheme; ECMWF: Reading, UK, 2000.

61. Raddatz, T.; Reick, C.; Knorr, W.; Kattge, J.; Roeckner, E.; Schnur, R.; Schnitzler, K.G.; Wetzel, P.; Jungclaus, J. Will the tropical land biosphere dominate the climate-carbon cycle feedback during the twenty-first century? Clim. Dyn. 2007, 29, 565-574.

62. Krinner, G.; Viovy, N.; de Noblet-Ducoudré, N.; Ogée, J.; Polcher, J.; Friedlingstein, P.; Ciais, P.; Sitch, S.; Prentice, I.C. A dynamic global vegetation model for studies of the coupled atmosphere-biosphere system. Glob. Biogeochem. Cycles 2005, 19, 1-44.

63. Bondeau, A.; Smith, P.C.; Zaehle, S.; Schaphoff, S.; Lucht, W.; Cramer, W.; Gerten, D.; LOTZE-CAMPEN, H.; Müller, C.; Reichstein, M.; et al. Modelling the role of agriculture for the 20th century global terrestrial carbon balance. Glob. Chang. Biol. 2007, 13, 679-706.

64. Masson, V.; Champeaux, J.L.; Chauvin, F.; Meriguet, C.; Lacaze, R. A global database of land surface parameters at 1-km resolution in meteorological and climate models. J. Clim. 2003, 16, 1261-1282.

65. Lawrence, P.J.; Chase, T.N. Investigating the climate impacts of global land cover change in the community climate system model. Int. J. Climatol. 2010, 30, 2066-2087.

66. Loveland, T.; Reed, B.; Brown, J.; Ohlen, D.; Zhu, Z.; Yang, L.; Merchant, J. Development of a global land cover characteristics database and IGBP DISCover from $1 \mathrm{~km}$ AVHRR data. Int. J. Remote Sens. 2000, 21, 1303-1330.

67. Mitchell, T.D.; Carter, T.R.; Jones, P.D.; Hulme, M.; New, M. A Comprehensive Set of High-Resolution Grids of Monthly Climate for Europe and the Globe: The Observed Record (1901-2000) and 16 Scenarios (2001-2100); Tyndall Centre for Climate Change Research Working Paper; Tyndall Centre for Climate Change Research: Norwich, UK, 2004; Volume 55, p. 25.

68. Verger, A.; Baret, F.; Weiss, M.; Lacaze, R.; Makhmara, H.; Pacholczyk, P.; Smets, B.; Kandasamy, S.; Vermote, E. LAI, FAPAR and FCOVER products derived from AVHRR long time series: Principles and evaluation. In Proceedings of the EGU General Assembly, Vienna, Austria, 22-27 April 2012; EGU General Assembly Conference Abstracts; Volume 14, p. 7844.

69. Feddema, J.J.; Oleson, K.W.; Bonan, G.B.; Mearns, L.O.; Buja, L.E.; Meehl, G.A.; Washington, W.M. The importance of land-cover change in simulating future climates. Science 2005, 310, 1674-1678.

70. Monerie, P.A.; Fontaine, B.; Roucou, P. Expected future changes in the African monsoon between 2030 and 2070 using some CMIP3 and CMIP5 models under a medium-low RCP scenario. J. Geophys. Res. 2012, 117, doi:10.1029/2012JD017510.

71. Flato, G.; Marotzke, J.; Abiodun, B.; Braconnot, P.; Chou, S.C.; Collins, W.; Cox, P.; Driouech, F.; Emori, S.; Eyring, V.; et al. Evaluation of climate models. In Climate Change 2013: The Physical Science Basis; Contribution of Working Group I to the Fifth Assessment Report of the Intergovernmental Panel on Climate Change; Cambridge University Press: Cambridge, UK, 2013; pp. 741-866. 
72. Diallo, I.; Sylla, M.B.; Camara, M.; Gaye, A.T. Interannual variability of rainfall over the Sahel based on multiple regional climate models simulations. Theor. Appl. Climatol. 2013, 113, 351-362.

73. Akinsanola, A.; Ogunjobi, K. Evaluation of present-day rainfall simulations over West Africa in CORDEX regional climate models. Environ. Earth Sci. 2017, 76, 366.

74. Verstraete, M.; Dickinson, R. Modeling surface processes in atmospheric general circulation models. Ann. Geophys. Ser. B 1986, 4, 357-364.

75. Sellers, P.; Berry, J.; Collatz, G.; Field, C.; Hall, F. Canopy reflectance, photosynthesis, and transpiration. III. A reanalysis using improved leaf models and a new canopy integration scheme. Remote Sens. Environ. 1992, 42, 187-216.

76. Betts, A.K.; Hong, S.Y.; Pan, H.L. Comparison of NCEP-NCAR reanalysis with 1987 FIFE data. Mon. Weather Rev. 1996, 124, 1480-1498.

77. Pitman, A.J. The evolution of, and revolution in, land surface schemes designed for climate models. Int. J. Climatol. 2003, 23, 479-510.

78. Pielke, R.A.; Avissar, R.; Raupach, M.; Dolman, A.J.; Zeng, X.; Denning, A.S. Interactions between the atmosphere and terrestrial ecosystems: Influence on weather and climate. Glob. Chang. Biol. 1998, 4, 461-475.

79. Quesada, B.; Arneth, A.; Noblet-Ducoudré, N. Atmospheric, radiative, and hydrologic effects of future land use and land cover changes: A global and multimodel climate picture. J. Geophys. Res. 2017, doi:10.1002/2016JD025448.

80. Lorenz, R.; Pitman, A.; Donat, M.; Hirsch, A.; Kala, J.; Kowalczyk, E.; Law, R.; Srbinovsky, J. Representation of climate extreme indices in the ACCESS1. 3b coupled atmosphere-land surface model. Geosci. Model Dev. 2014, 7, 545-567.

81. Spracklen, D.V.; Arnold, S.R.; Taylor, C. Observations of increased tropical rainfall preceded by air passage over forests. Nature 2012, 489, 282-285.

82. Davin, E.L.; de Noblet-Ducoudré, N. Climatic impact of global-scale deforestation: Radiative versus nonradiative processes. J. Clim. 2010, 23, 97-112.

83. Lejeune, Q.; Davin, E.L.; Guillod, B.P.; Seneviratne, S.I. Influence of Amazonian deforestation on the future evolution of regional surface fluxes, circulation, surface temperature and precipitation. Clim. Dyn. $2015,44,2769-2786$. 